\author{
Miloš Luković \\ (Instytut Bałkanistyki Serbskiej Akademii Nauk i Sztuk, Belgrad)
}

\title{
Sezonowe migracje pasterzy na Bałkanach: charakter, historia, transformacje ${ }^{1}$
}

\author{
Seasonal livestock movements in the Balkans: character, history, \\ transformations
}

\section{STRESZCZENIE:}

W trakcie długiego okresu historycznego głównym rodzajem pasterstwa na Półwyspie Bałkańskim były migracje sezonowe pasterzy z wielkimi stadami owiec (lub, w mniejszym stopniu, kóz) między letnimi a zimowymi pastwiskami. Podczas lata wypasano swoje stada na pastwiskach w wysokich górach, podczas gdy jesienią owce zaganiano do ciepłych nizin nadmorskich oraz do ciepłych kotlin i dolin rzek, w których było na tyle dużo trawy, że owce mogły przetrwać do wiosny i kolejnego okresu wegetacyjnego w górach. Działalność pasterska tego rodzaju ciągle ulegała zmianom. Był to długi, kilkuwieczny proces, który przechodził przez różne etapy i rozwijał się różnie w poszczególnych częściach Półwyspu Bałkańskiego (w zależności od konkretnych geograficznych, społecznych i politycznych warunków i okoliczności). Mimo wszelkich zmian, których doświadczyły w średniowieczu i podczas kilku stuleci rządów osmańskich na Bałkanach, wielkie sezonowe migracje pasterzy trwały aż do XX wieku. W zredukowanej i zmodyfikowanej formie istnieją do dziś. W niniejszej pracy rozważane są następujące kwestie: wpływ zmian politycznych od końca XVIII do początku XX wieku na sezonowe migracje pasterzy na Bałkanach; świadectwa podróżników i badania dotyczące Bałkanów związane z sezonowymi migracjami pasterzy; niedawne (reliktowe) strefy sezonowych migracji pasterzy na Bałkanach; charakter migracji sezonowych pasterzy na Bałkanach; organizacja społeczna i status pasterzy wołoskich na Bałkanach w średniowieczu oraz zmiany statusu i sposobu organizacji migracji sezonowych w okresie osmańskim. W związku z tym konieczne jest również wyjaśnienie pojęcia Pótwysep Bałkański/Bałkany.

Słowa kluczowe: Bałkany, pasterze, sezonowe migracje, historia, transhumancja

${ }^{1}$ Artykuł powstał w ramach projektu Kultura ludowa Serbów między Wschodem i Zachodem (2011-2015) podjętego przez Instytut Bałkanistyki Serbskiej Akademii Nauk i Sztuk w Belgradzie, finansowanego przez Ministerstwo Edukacji i Nauki Republiki Serbii. 
W ciagu długiego okresu historycznego głównym rodzajem pasterstwa na Półwyspie Bałkańskim były migracje sezonowe pasterzy z wielkimi stadami owiec lub (w mniejszym stopniu) kóz między letnimi a zimowymi pastwiskami. Podczas lata pasterze wypasali swoje stada na pastwiskach w wysokich górach, zaś jesienią owce zaganiano na ciepłe nadmorskie niziny oraz do kotlin i dolin rzek, w których było na tyle dużo trawy, żeby owce mogły przetrwać do wiosny i kolejnego okresu wegetacyjnego w górach. Działalność pasterska tego rodzaju ulegała ciągłym zmianom. Był to długi, kilkuwiekowy proces, który przechodził różne etapy i rozwijał się różnie w poszczególnych częściach Półwyspu Bałkańskiego - w zależności od konkretnych warunków geograficznych, społecznych i politycznych. Mimo wszelkich przemian wielkie sezonowe migracje pasterzy trwały aż do XX wieku. W zredukowanej i zmodyfikowanej formie istnieją też do dziś.

Niełatwo jest zrekonstruować, nawet w ogólnych rysach, cały ów proces historyczny. Zachowanych źródeł historycznych dotyczących średniowiecza jest stosunkowo niewiele - w zachodniej części Półwyspu Bałkańskiego więcej niż we wschodniej. O wcześniejszych epokach świadczą tylko dane archeologiczne. Istotne źródła z czasów osmańskich były publikowane dopiero po II wojnie światowej (głównie osmańskie księgi podatkowe). W XIX i XX wieku formy i praktyki pasterskich migracji sezonowych zostały dobrze opisane, lecz te opisy dotyczą niedawnego stanu rzeczy. Stąd narzuca się potrzeba, by do tej rozległej i zróżnicowanej tematyki podchodzić stopniowo, począwszy właśnie od nieodległej sytuacji, która jest dla nas zrozumiała i bliżej znana, a następnie cofać się $\mathrm{w}$ przeszłość. W ten sposób będziemy mogli naświetlić charakter ówczesnych sezonowych migracji pasterzy oraz zidentyfikować główne determinujące je czynniki. Zamknie to cykl całej historii sezonowych migracji pasterzy na Bałkanach oraz ich długotrwałych transformacji. Warto natomiast zaczać od wyjaśnienia nazwy Półwysep Bałkański / Bałkany.

\section{PÓŁWYSEP BAŁKAŃSKI / BAŁKANY}

Używanie terminu Półwysep Bałkański (Bałkany) posiada tradycję dłuższą niż dwa stulecia. Pierwotnie służył on do nazywania wyłącznie konkretnej przestrzeni geograficznej na południowym wschodzie Europy. Na początku XIX wieku, pod wpływem idei geograficznych niemieckiego przyrodnika Alexandra von Humboldta (1769-1859) oraz chorwackiego pisarza i historyka Pavao Rittera Vitezovicia (1652-1713), pojawiło się dążenie do tego, by przy pokazywaniu przestrzeni Europy polityczne 
i historyczne całości zamienić na całości przyrodnicze lub geograficzne. Wiedziony tymi koncepcjami niemiecki geograf Johann August Zeune (1778-1853) zapragnął poznać obszar europejskiej Turcji i w tym celu odbył w roku 1806 podróż z Belgradu przez Nisz i Sofię aż po Stambuł. Efektem wyprawy było jego najważniejsze dzieło Balkanhalbinsel (Pótwysep Bałkański), opublikowane w roku $1808^{2}$. Zeune nazwał ten półwysep od pasma górskiego Balkan (nazywano je tak po turecku), ciągnącego się od Morza Czarnego ku wnętrzu Półwyspu. W ten sposób określenie Pótwysep Bałkański, używane czasami w skróconej formie Bałkany, stało się częścią europejskiej nomenklatury geograficznej. Musiało minąć 70 lat (do Kongresu Berlińskiego w roku 1878), by te określenia w praktyce zyskały przewagę nad terminami oznaczającymi granice państwowe lub obszary historyczne na terytorium południowo-wschodniej Europy.

Bezpośrednio przed I wojną światową termin Bałkany nabrał w europejskim życiu publicznym negatywnej konotacji ze względu na rozparcelowanie europejskiej części Imperium Osmańskiego po wojnach bałkańskich w latach 1912-1913, dokonane przez Grecję, Bułgarię, Serbię i Czarnogórę. Proces ten nazwano batkanizacja (ang. balkanization; niem.

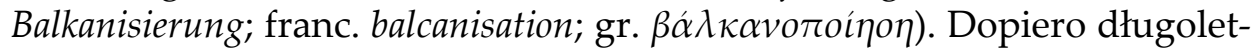
nie badania prowadzone przez serbskiego geografa i antropogeografa Jovana Cvijicia (1865-1928) ${ }^{3}$ oraz jego uczniów i kontynuatorów przyczyniły się do zmiany skojarzeń, jakie przywodziła nazwa Półwysep Bałkański ${ }^{4}$. Sezonowe migracje pasterzy były charakterystyczne dla większej części Półwyspu Bałkańskiego.

\section{WPŁYW ZMIAN POLITYCZNYCH OD KOŃCA XVIII DO POCZĄTKU XX WIEKU NA SEZONOWE MIGRACJE PASTERZY NA BAŁKANACH}

Na przełomie XVIII i XIX wieku doszło do znaczących zmian politycznych na południowym wschodzie Europy, co było związane z naj-

${ }^{2}$ J. A. Zeune, Balkanhalbinsel, Berlin 1808.

${ }^{3}$ J. Cvijić w czasie I wojny światowej (1917-1918) wykładał na Sorbonie w Paryżu, gdzie był profesorem honorowym. Na podstawie wykładów Cvijicia i wszystkich jego prac powstała obszerna i syntetyczna monografia pod tytułem La Péninsule balkanique: géographie humaine, Paris 1918. Później opublikowano w Belgradzie rozszerzone wydanie w języku serbskim: Balkansko poluostrvo i južnoslovenske zemlje. Doczekało się ono kilku wznowień (1918, 1922, 1966, 1989, 1996, 2000 i inne), por. J. Cvijić, Balkansko poluostrvo i južnoslovenske zemlje, Beograd 1966.

${ }^{4}$ Obszernie pisałem o tym w Balkanistika (balkanologie) v Srbsku v obdobi 1991-2013, „Historica. Revue pro Historii a Př́buzné Vědy“ 2014, s. 86-104, szczeg. s. 101-104; por. także P. Mutavdžić, Balkan i balkanologija: uvod u studije jugoistočne Evrope, Beograd 2013, s. 49-50. 
ważniejszymi wydarzeniami na scenie europejskiej5. Najpierw Napoleon zlikwidował w roku 1797 Republikę Wenecka, następnie w roku 1808 Republikę Dubrownicka, przejmując władzę nad posiadłościami tych dwóch republik na wschodnim wybrzeżu Adriatyku. Po upadku Napoleona i po kongresie wiedeńskim (1815) przejęło te obszary Cesarstwo Austrii, rozciągając swoją dominację na całym terytorium wschodniego wybrzeża Adriatyku - od półwyspu Istria na północy do Zatoki Kotorskiej i półwyspu Spicz niedaleko miasta Bar (które pozostało w granicach Imperium Osmańskiego). W ten sposób Cesarstwo Austrii zyskało w tej części Półwyspu Bałkańskiego nowa jeszcze dłuższą granicę z państwem osmańskim, która biegła wzdłuż najwyższego pasma Gór Dynarskich, oddzielającego wąskie wybrzeże adriatyckie od wnętrza półwyspu. Granica habsbursko-osmańska na północy i na zachodzie ustabilizowała się w pierwszej połowie XVIII wieku po serii wojen (pokój belgradzki w 1739 r.) na linii środkowych i południowych Karpat do Wąwozu Djerdapskiego, dalej wzdłuż Dunaju do Belgradu, potem wzdłuż Sawy do ujścia rzeki Una. Z drugiej strony Rosja w roku 1812 otrzymała dostęp do rzeki Prut i delty Dunaju, zajęła Besarabię i zaczęła odgrywać coraz aktywniejszą rolę w politycznych wydarzeniach na Bałkanach i w Europie południowo-zachodniej.

W granicach państwa osmańskiego na południe od Dunaju i Sawy pod koniec XVIII wieku i w pierwszych dekadach XIX wieku również doszło do znaczących przemian. Niewielkiej Czarnogórze, osłoniętej najpierw weneckim, a potem habsburskim zapleczem adriatyckim, udało się wyrwać spod dominacji osmańskiej i rozpocząć powiększanie swojego wpływu i terytorium na sąsiadujące obszary. Na obszarze Imperium Osmańskiego, w okolicach Sawy i Dunaju (tak zwany Paszalik Belgradzki i sąsiednie rejony), wybuchło wielkie powstanie antytureckie, zapamiętane w historiografii jako I powstanie serbskie (1804-1813), a potem jeszcze krótkie II powstanie serbskie (1815). Przetarły one szlaki do utworzenia wasalnego, autonomicznego Księstwa Serbii, które formalnie status uzyskało w roku 1830. Powstanie greckie w roku 1821 przyczyniło się do utworzenia niezależnej Grecji w południowej części Półwyspu. Wszystkie trzy formacje państwowe poszerzały swoje terytoria w ciągu XIX wieku kosztem Imperium Osmańskiego. Po kongresie berlińskim w roku 1878 stopniowo dołączyła do nich również Bułgaria. Cały ten proces zakończył się wraz z wojnami bałkańskimi w latach 1912 i 1913, kiedy Imperium Osmańskie zostało wyparte z niemalże całej powierzchni Półwyspu Bałkańskiego

${ }^{5} \mathrm{Na}$ temat historii Bałkanów w okresie od końca XVIII do początku XX wieku istnieje obszerna literatura. Tutaj zwracam uwagę na S. Pavlović, Istorija Balkana 1804-1945, Beograd 2001. 
(w ramach Imperium pozostała tylko mała jego część przy szlaku do Stambułu). Wtedy powstało też nowe państwo bałkańskie - Albania.

Wszystkie te wydarzenia polityczne na Bałkanach, trwające ponad 100 lat, którym towarzyszyły znaczące zmiany społeczne zachodzące w każdym z krajów, miały duży wpływ również na tradycyjne pasterstwo oraz sezonowe migracje pasterzy. Młode państwa bałkańskie podejmowały kroki w celu uregulowania całego systemu sezonowych migracji pasterzy i zaprowadzenia porządku w tej działalności gospodarczej, która zresztą coraz bardziej podupadała. Natomiast na znaczeniu zyskiwało rolnictwo.

\section{ŚWIADECTWA PODRÓŻNIKÓW I BADANIA BAŁKANÓW ZWIĄZANE Z SEZONOWYMI MIGRACJAMI PASTERZY}

Dowody na sezonowe migracje pasterzy w poszczególnych rejonach Bałkanów pozostawiło również wielu cudzoziemców, zarówno w XIX wieku, jak i w pierwszych dekadach XX wieku: Henry Holland w swoich dziennikach z podróży po Albanii ${ }^{6}$; François Pouqueville w dzienniku podróży po Grecjï; William $\mathrm{M}$. Leake $\mathrm{w}$ dziennikach podróży po północnej Grecji ${ }^{8}$; Emile Picot $\mathrm{w}$ dzienniku podróży po (historycznej) Macedonii ${ }^{9}$; Konstantin Jireček w dzienniku podróży po Bułgarii ${ }^{10}$; Gustav Weigand w swoim obszernym dziele o Arumunach (Wołochach) w różnych częściach Bałkanów ${ }^{11}$; Pavel Rovinski we wszechstronnych studiach o Czarnogórze, opartych na wrażeniach $\mathrm{z}$ wieloletniego pobytu w tym kraju'12; Lovro Mihačević w dzienniku podróży po Albanii, Epirze i Macedonii ${ }^{13}$; Alan John Bayard Wace i Moris Scott Thompson w swych dziennikach podróży po północnym Pindos ${ }^{14}$ oraz inni badacze tego obszaru. Na początku XX wieku Cvijić zainaugurował program badań antropogeograficznych problemów Półwyspu Bałkańskiego ${ }^{15}$. Uczniowie

${ }^{6}$ H. Holland, Travels in Albania, London 1819.

${ }^{7}$ F. Pouqueville, Voyage de la Grèce, Paris 1824.

${ }^{8}$ W. M. Leake, Travels in northern Greece, London 1835.

${ }^{9}$ E. Picot, Les Roumains de la Macédoine, Paris 1875.

${ }^{10}$ K. Jireček, Cesty po Bulharsku, Praha 1888.

11 G. Weigand, Die Aromunen, I-II, Leipzig 1894-1895 (= G. Vajgand, Aromuni, I-II, Beograd 1995).

${ }^{12}$ P. A. Rovinski, Czernogoria v eja proszlom i nastojasztem, Sanktpeterburg 1897.

${ }^{13}$ L. Mihačević, Po Albaniji. Dojmovi s puta, Zagreb 1911.

${ }^{14}$ A. J. B. Wace, M. S. Thompson, The nomads of the Balkans: an acocount of life and customs among the Vlachs of northern Pindus, London 1914 (= A. J. B. Veis, M. S. Tompson, Balkanski nomadi: prikaz života i običaja Vlaha sa severnih Pinda, Pančevo 2009).

${ }^{15} \mathrm{~J}$. Cvijić, Antropogeografski problemi Balkanskog poluostrva, Srpski Etnografski Zbornik (serija: Naselja srpskih zemalja. Rasprave i građa) IV, Beograd 1902, s. I-CCXXXVI. 
i następcy Cvijicia w ciągu kolejnych dekad opublikowali, na podstawie obszernych badań terenowych, szereg studiów etnograficznych i antropogeograficznych dotyczących poszczególnych regionów i sfery społeczeństwa patriarchalnego na Bałkanach, w którym tradycyjne pasterstwo odgrywało główną rolę ${ }^{16}$. Podczas I wojny światowej ukazały się także studia porównawcze historyka prawa Karela Kadleca na temat Wołochów w rejonie Karpat i na Bałkanach ${ }^{17}$, które przetarły kierunki ku nowej wiedzy i wniosków. Wszystkie te badania wykazały, że określony typ pasterstwa wymagał również określonej organizacji i formy pracy, co w poszczególnych częściach Bałkanów w XIX i pierwszej połowie XX wieku wdrażano w różny sposób. Ponadto została wytłumaczona bezpośrednia zależność pasterstwa od rzeźby i innych właściwości geograficznych terenu, w czym największy wkład miał Cvijić.

Cvijić uważał, że przestrzeń Półwyspu Bałkańskiego można podzielić na cztery wielkie naturalne całości ze względu na ich charakterystyki morfologiczne, etnograficzne oraz historyczne ${ }^{18}$. Pierwszą jest Rejon Egejski, który - podobnie jak śródziemnomorski - stanowi oddzielną część (właściwie południową część Bałkanów). Trzy pozostałe składają się na blok kontynentalny: 1) Rejon Wschodni (większa część terytorium dzisiejszej Bułgarii i cały basen rzeki Marica), 2) Rejon Morawsko-Wardarski lub Centralny, 3) Pindosko-Dynarski lub Zachodni Rejon Bałkanów. Za podstawową linię podziału geograficznego na Półwyspie Bałkańskim Cvijić uznał granicę pomiędzy Rejonem Egejskim i blokiem kontynentalnym, rozciągającym się skośnie od Zatoki Salonickiej na Morzu Egejskim do Zatoki Artańskiej na Morzu Jońskim. Według podziału Cvijicia Epir i cały obszar północno-zachodniej Grecji należą do bloku kontynentalnego. Właśnie ze względu na duże różnice geograficzne sposób życia w bloku kontynentalnym w przeszłości znacznie się różnił w stosunku do Rejonu Egejskiego. Sezonowe migracje pasterzy były charakterystyczne dla obszarów górzystych bloku kontynentalnego, a zdecydowanie mniejsze dla Rejonu Egejskiego, o bardzo suchym klimacie, gdzie góry porośnięte wysuszoną trawą nie mogły być użytkowane do wypasania owiec.

Cvijić zwrócił szczególną uwagę na niektóre osobliwości Rejonu Pindoskiego, wchodzącego w skład Zachodnich Bałkanów, mające ważne znaczenie dla sezonowych migracji pasterzy w porównaniu z Rejonem

${ }^{16}$ Naselja srpskih zemalja: naselja, poreklo stanovništva, običaji, red. B. Čeliković, Beograd 2011, s. 775-796.

${ }^{17}$ K. Kadlec, Valaši a valašské právo v zemích slovanských a uherskýh, Praha 1916.

${ }^{18} \mathrm{~J}$. Cvijić, Balkansko poluostrvo, s. 35-100. 


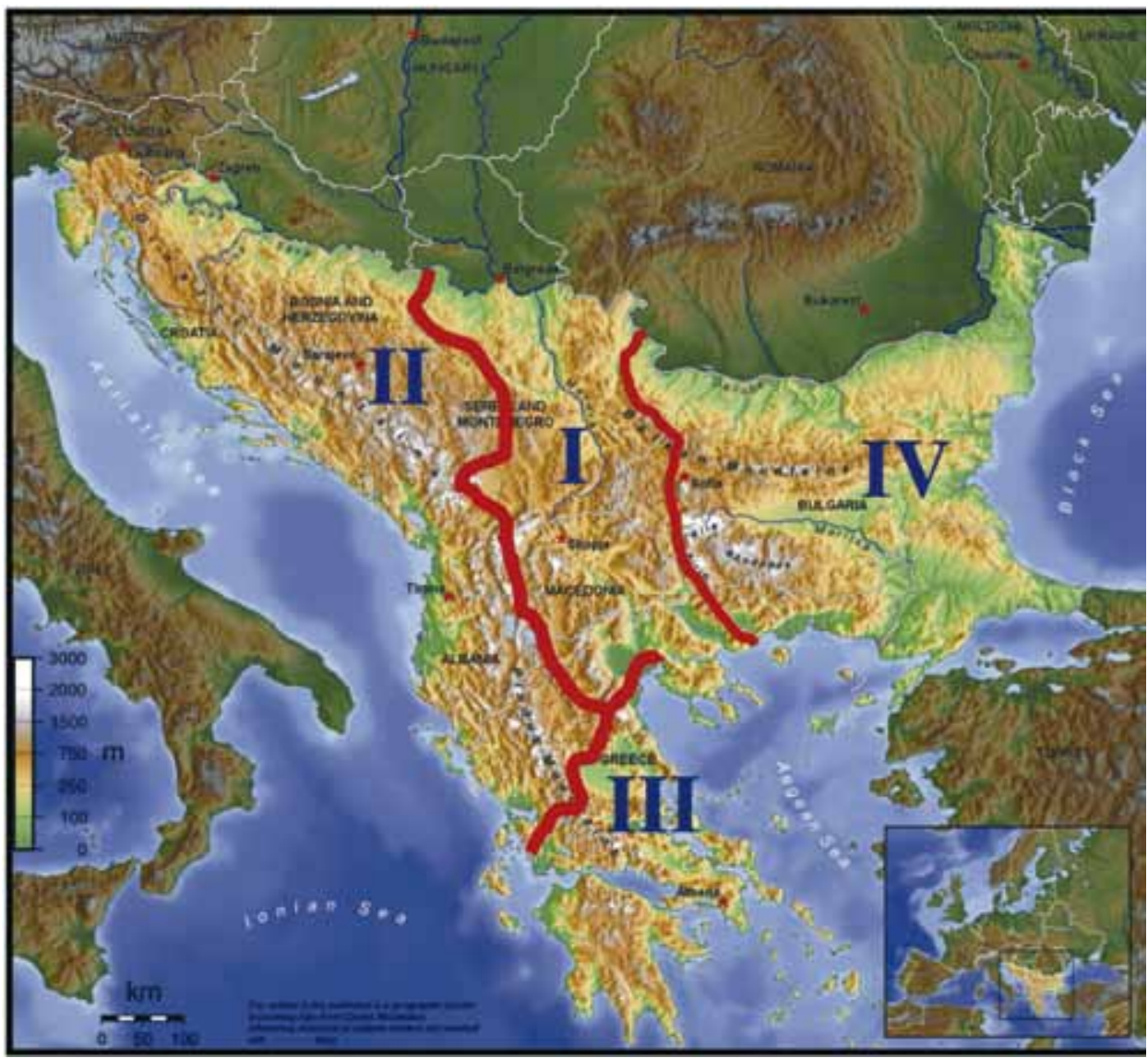

Ryc. 1. Cztery wielkie naturalne części Półwyspu Bałkańskiego ze względu na ich cechy morfologiczne, etnograficzne oraz historyczne: I. Rejon Morawsko-Wardarski (Centralny). II. Rejon Pindosko-Dynarski (Zachodni). III. Rejon Egejski. IV. Rejon Wschodni (J. Cvijić, Balkansko poluostrvo i južnoslovenske zemlje. Osnovi antropogeografije, Beograd 1966, s. 35-87)

Dynarskim (który również wchodzi w skład Rejonu Zachodniego) ${ }^{19}$. Mimo że nieco węższy od Rejonu Dynarskiego, Rejon Pindoski jest również dość rozległy i podzielony. Główną oś Rejonu Pindoskiego stanowi wieniec gór Šar i Pindos, które ciągną się równolegle do Morza Adriatyckiego i Jońskiego w kierunku północ-południe. Góry te są bardziej oddalone od Morza Adriatyckiego i Jońskiego, a pomiędzy nimi znajdują się duże obszary równinne. Morze Adriatyckie jest w tej części wybrzeża płytkie, a tym samym niedostępne dla statków i tylko miejscowość Durrës rozwinęła się

${ }^{19}$ Ibidem, s. 69-70, 83-87. 
jako port. W ten sposób położenie gór Šar i Pindos różni się od położenia najwyższego grzbietu Gór Dynarskich, które położone są bardzo blisko morza (u podnóża tych gór morze jest głębokie i jest mnóstwo zatok, w których rozwinęły się ważne adriatyckie porty). Oprócz tego Rejon Pindoski od wschodu jest stosunkowo oddalony od ważnych szlaków komunikacyjnych, które zawsze biegły przez połączone doliny rzek Morawy i Wardar, łącząc obszary naddunajskie z wybrzeżem egejskim. Ze względu na opisane warunki Rejon Pindoski w okresie antycznym, średniowiecznym i osmańskim miał wyraźnie peryferyjny charakter, a jego mieszkańcy byli raczej odizolowani. Miało to wpływ na długie trwanie archaicznych form życia gospodarczego i społecznego oraz na zachowanie sezonowych migracji pasterzy aż do pierwszego dziesięciolecia XX wieku.

Rejon Centralny (Morawsko-Wardarski) ograniczony jest na wschodzie północno-zachodnim grzbietem Starej Płaniny (na granicy dzisiejszej Serbii i Bułgarii) i masywem Rodopów. Dalej na wschód rozpościera się Rejon Wschodni Półwyspu Bałkańskiego. Na obrzeżach i wewnątrz Rejonu Centralnego znajduje się więcej wysokich gór, ale wśród nich jest również więcej dolin i kotlin rzecznych z klimatem śródziemnomorskim (Powardarie, Struma, Owcze Pole, Metochia) lub umiarkowanym klimatem kontynentalnym (Pomorawie, Kraina Timoku). Wokół zatoki Morza Egejskiego, u ujścia Wardaru i Strumy (Zatoka Salonicka i Orfańska), znajdują się rozległe niziny, a klimat śródziemnomorski sięga w głąb Rejonu Centralnego. Dlatego też ten rejon jest również dość atrakcyjny dla sezonowych migracji pasterzy. To samo w nieco mniejszym stopniu dotyczy łańcucha górskiego Bałkan (Stara Płanina), rozciągającego się środkiem Rejonu Wschodniego (w kierunku zachód-wschód, na terytorium dzisiejszej Bułgarii), od którego cały Półwysep Bałkański przyjął nazwę.

Oprócz cech geograficznych należy mieć na uwadze cechy komunikacyjne Bałkanów, które istniały w przeszłości. W średniowieczu rozwinęła się szeroka sieć szlaków dla karawan, które dochodziły do wybrzeży Morza Adriatyckiego, Egejskiego i Czarnego ${ }^{20}$, przy czym Rejon Pindoski był najmniej dostępny. Takie połączenia poszczególnych części Półwyspu Bałkańskiego umożliwiały przez wieki nie tylko handlowe powiązanie lądowej części Półwyspu z wybrzeżami, ale także większe migracje i mieszanie się mieszkańców, w tym również sezonowe migracje pasterzy aż po XIX wiek, oraz budowę kolei i dróg.

${ }^{20}$ Więcej na ten temat pisze C. J. Jireček, Die Handelsstrassen und Bergwerke von Serbien un Bosnien während des Mittelalters, Prag 1879 (= K. Jireček, Trgovački putevi i rudnici Srbije i Bosne u srednjem vijeku, [w:] Zbornik Konstantina Jirečeka I, red. M. Dinić, Beograd 1959, s. 295-304); G. Škrivanić, Putevi u srednovekovnoj Srbiji, Beograd 1974. 


\section{NIEDAWNE (RELIKTOWE) STREFY SEZONOWYCH MIGRACJI PASTERZY NA BAtKANACH}

Rejon Zachodni. Jak już wspomniano, sezonowe migracje pasterzy miały miejscew RejoniePindoskim, który prawiew całości wchodziłw skład Imperium Osmańskiego aż do wojen bałkańskich w latach 1912-1913. Pasterze Rejonu Pindoskiego - w największej mierze Arumuni (Wołosi) ${ }^{21}$, mniej było Albańczyków (Malisorzy, Mirdytowie), a jeśli mowa o ludności macedońsko-słowiańskiej, to tylko „plemię" Mijakowie (z regionu górskiego na północ od miasta Debar) - brali udział w migracjach sezonowych w kierunku pomorza adriatyckiego, egejskiego i jońskiego. Przy tym tylko Arumuni (w największej ilości przypadków) nie mieli stałych siedlisk, podczas gdy pozostali mieli swoje wsie, najczęściej u podnóży gór, gdzie wypasali swoje stada. Pasterze arumuńscy z południowych gór Wieńca Szarsko-Pindoskiego (na terenie dzisiejszej Grecji) schodzili do wybrzeża jońskiego przy Zatoce Artańskiej oraz do sąsiedniego rejonu Akarnanii i wybrzeża egejskiego (Zatoka Wołoska, Urumluk pod Olimpem), a także do dużej ciepłej kotliny Tesalii. Z Wieńca Szarsko-Pindoskiego, na północ od Jeziora Ochrydzkiego, z prawej strony Czarnego Drimu (Szar Płanina, Korab, Bistra, Krczin), Arumuni, Albańczycy (Dibralczycy, Ljumljanie i inni) i macedońscy Mijakowie schodzili (doliną Wardaru lub wzdłuż jeziora Prespa) do wybrzeża egejskiego, na równinę przy ujściu Wardaru i Zatoce Salonickiej, zaś niektórzy zatrzymywali się w ciepłych kotlinach macedońskich. Natomiast z gór Wieńca Pindoskiego, z terytorium dzisiejszej Albanii, albańscy Mirdytowie, Dukadzinowie i inni oraz Arumuni (Farszerioci) kierowali się na wybrzeża Adriatyku do niziny przy ujściu rzek Szkumby, Semeni, Wojuszy (Elbasan, Musakia, Malakastra) i do ujścia Drimu i Bojany (Ljesz, Szkodra). Pomiędzy wymienionymi wspólnotami pasterskich często dochodziło do konfliktów i odbierania sobie górskich hal, z czym miała kłopot nawet władza osmańska. Po kongresie berlińskim oddano Grecji Tesalię (z mniejszą częścią południowego Epiru), która od dawien dawna była obszarem zimowania dla arumuńskich pasterzy z Gór Pindoskich. Przecięto w ten sposób szlaki migracji sezonowych z Tesalii w kierunku Pindosu (który pozostał w granicach

\footnotetext{
${ }^{21}$ Członkowie tej romańskiej społeczności na Bałkanach określają siebie Arumunami (Arămăn, Aromăn, Romăn, Răman), z rzadkimi wyjątkami (na przykład Wołosi z rejonu Meglena w północnej Grecji - megleńskimi Wołochami), ale sąsiednie i inne narody nazywają ich Wołochami (Vlasi). Serbowie stosują alternatywne określenie Cyncarzy. Por. J. Cvijić, Balkansko poluostrvo, s. 138-142, 199 -201; G. Vajgand, Aromuni, t. I, s. 94, 95, 226-230, 238, 247, 254, 255, 256, 258; Zbornik na trudovi od Meǵunarodniot naučen simpozijum Vlasite na Balkanot održan na 7-8 noemvri 2003 vo Skopje, red. S. Kiselinovski, D. Dimčev, Skopje 2005.
} 
Turcji), co utrudniło przemieszczanie się i wprowadziło konieczność załatwiania formalności celnych. Granica ta została zlikwidowana po wojnach bałkańskich, ale wówczas oraz po I wojnie światowej powstały nowe granice $\mathrm{z}$ Jugosławią i Bułgaria, które przecięły inne trasy migracji sezonowych pasterzy arumuńskich.

W regionach, gdzie odbywała się sezonowa migracja na długich szlakach, pasterze organizowali się $\mathrm{w}$ zrzeszenia. Ich trwałość była ograniczona jednym sezonem wypasu w górach, ale można je było odnawiać $\mathrm{w}$ kolejnych sezonach. Ten typ zrzeszania u pasterzy arumuńskich nosił nazwę tajfa (tur. ta'ifesi), a u pasterzy macedońsko-słowiańskich karasznica (maced. karašnica, wcześniej także $k^{\prime} t u n$ ) ${ }^{22}$. Letnie stanice pasterzy arumuńskich w górach nazywano mandrami. Stanice obejmowały kilka kolib (arum. kaliwa) i obiektów dla zwierząt. Koliby znajdowały się blisko siebie i przypominały skupione wsie. Albańscy i macedońsko-słowiańscy pasterze mieli na górskich pastwiskach koliby pogrupowane według rodów i nazywali je baczilami (maced. bačilo).

W rejonie Gór Dynarskich występowały trzy strefy sezonowych migracji: przybrzeżna, centralna, peripanońska ${ }^{23}$. Strefa przybrzeżna rozciągała się wzdłuż wybrzeża adriatyckiego (od półwyspu Istria do ujścia rzeki Buny), a na lądzie od morza do grani pierwszych wysokich gór, które były mniej lub bardziej oddalone od wybrzeża (Welebit, Dinara, Biokovo, Czibulia, Weleż, Niedosz , Orjen, Lovćen, Rumija). Centralna strefa była także stosunkowo wąska, ale za to miała długość 500 kilometrów. Należały do niej pasma Gór Dynarskich: Komovi, Durmitor, Wolujak, Maglić, Zelengora, Bjelasica, Prenj, Črvsnica, Radusza, Witorog, Szator, Klekowacza. Ta strefa składała się z kilku mniejszych obszarów pasterskich znajdujących się na terenie dzisiejszej Czarnogóry oraz Bośni i Hercegowiny. Lika, leżąca na terytorium obecnej Chorwacji, w przeszłości była znaczącym mikroregionem pasterskim. Pasterze z Liki zaganiali swoje owce na kontynentalną (północną) stronę gór Welebit, a czasem nawet pozwalano im wypasać zwierzęta zimą w północnej Dalmacji (na południe od pasma Welebit). Na północ od strefy centralnej, w kierunku rzeki Sawy, leżało szerokie i zróżnicowane terytorium, które geografowie najczęściej nazywają peripanońskim. Rozciąga się ono pomiędzy rzekami Ibar i zachodnią Morawą na wschodzie (teren obecnej Serbii) do rzeki Uny, Gliny i Korany na zachodzie (w pasie granicznym dzisiejszej Bośni i Chorwacji).

${ }^{22}$ A. Matkovski, Nomadskoto stočartvo vo Makedonija od XIV do XIX vek, Skopje 1996, s. 155.

${ }^{23}$ M. Marković, Stočarska kretanja u dinarskim planinama, "Zbornik za Narodni Život i Običaje Južnih Slavena" 1971, 45, s. 523-549. 
Obecnie w rejonie Gór Dynarskich odbywają się także sezonowe migracje pasterzy, ale na krótszych szlakach. Pasterze mają tam swoje wioski i zajmują się rolnictwem, a zimą karmią zwierzęta sianem. Wspólnie wypasają bydło na pastwiskach położonych w stosunkowo niedalekich górach. Pastwiska, które kiedyś były wspólną własnością wielu wsi i jednostek samorządowych, dzisiaj należą do państwa. Na niektórych obszarach bydło jest zaganianie $w$ nieco bardziej oddalone góry, gdzie pasterze od wieków mają prawo do wypasania swojej trzody (kupione od "tureckich bejów"). Na pastwiskach tych znajdowały się stałe kwatery dla ludzi - chaty, tzw. katuny ${ }^{24}$. W każdej chacie mieszkała jedna rodzina. Wokół katunów rozstawione były pomieszczenia dla owiec. Każda rodzina zajmowała się swoim stadem i przygotowywaniem wyrobów mleczarskich. Ów rodzaj sezonowego pasterstwa miał ustalony system wypasania bydła na górskich pastwiskach (serb. izdig) oraz powrotu do rodzimej wsi ze zgromadzonymi produktami (serb. zdig/sjavak).

Rejon Centralny. W Rejonie Centralnym Bałkanów dochodziło do sezonowych migracji pasterzy w wielu kierunkach. Pasterze z gór południowej części Rejonu Centralnego (w pasie granicznym Serbii i Bułgarii oraz Macedonii i Bułgarii) schodzili na wybrzeża egejskie, byli to zasadniczo Arumuni, ale różnego pochodzenia: po grecku mówili Sarakaczanie i Aszanie (ci drudzy byli wyznania muzułmańskiego). Byli też nowsi arumuńscy koloniści z Rejonu Pindoskiego (Farszerioci, Gramostlioci), którzy pod koniec XVIII i na początku XIX wieku uciekli przed uciskiem Ali-paszy Janińskiego (największą część tych arumuńskich kolonistów przywiązał do wsi i miasteczek w strefie bitolijsko-kruszewackiej w południowo-zachodniej Macedonii). Arumuni zamieszkiwali także na terenach od kotliny Meglen do Jeziora Ohrydzkiego i Prespa. Gramostliotom (pochodzącym z gór Gramos na granicy dzisiejszej Albanii i Grecji) udało się zająć góry w południowej części dzisiejszej Republiki Macedonii (Belasica, Osogowo, Płaczkowica, Golak, Ograżden i inne) po wyparciu dotychczasowych tureckich pasterzy Juruków i słowiańskich Macedończyków, a pastwiska na niektórych górach odkupili od osmańskich bejów i uzyskali na nie dokument własności - tapię (tak zwane „góry tapialne").

${ }^{24}$ Katun w dzisiejszych czasach posiada następujące znaczenia: w języku serbskim, chorwackim i bułgarskim „miejsce, gdzie latem w górach wypasa się dojne bydło (zwłaszcza owce)”; w języku rumuńskim cătun to "niewielka grupa gospodarstw chłopskich";

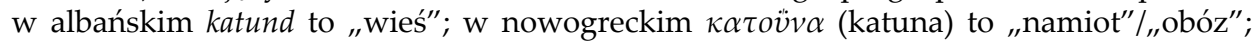
w romskim katuna oznacza čerga (pojazd z namiotem); zob. Enciklopedija Jugoslavije, t. 5, gl. red. M. Krleža, Zagreb 1957, s. 230-231 (hasło katun). 
Z gór pomiędzy południową Morawą i źródłami Strumy (Streszner, Czemernik, Wardenik, Dukat i innych gór wokół Jeziora Własinskiego) pomiędzy Wardarem i Strumą (Belasica, Osogowo, Galiczica, Buszowa, Mokra, Jakupica) słowiańscy, wołoscy i juruczcy pasterze schodzili na przezimowanie wokół Jeziora Dojrańskiego, Serezu, Dramy oraz zatok Morza Egejskiego (Kawalska, Orfańska, Salonicka), również na Półwysep Chalkidiki (koło Poligirosu).

Północna część Rejonu Centralnego (w dorzeczu trzech Moraw, na terenie dzisiejszej Serbii) była strefą osłabionego pasterstwa. Na tym obszarze w pierwszej połowie XIX wieku rozwinęło się autonomiczne Księstwo Serbskie, gęsto zasiedlone, toteż wszystkie niższe tereny w głębi kraju i wzdłuż Sawy i Dunaju zostały przekształcone w ziemie rolne. W ten sposób wielu pasterzy zmieniło się w rolników. Jednak na obrzeżach Księstwa Serbskiego znajdowały się wyższe góry (Stara Płanina, Rtanj, Kopaonik, Golia, Złatar, Zlatibor, Góry Walewskie), które umożliwiały sezonowe migracje pasterzy, spędzających zimy w stałych osiedlach u podnóży tych gór lub w nieco oddalonych oraz ciepłych rzecznych dolinach Południowej i Zachodniej Morawy i Toplicy. Ci pasterze byli Serbami (najczęściej pochodzącymi z rejonu Dynarskiego i Szopskiego) bądź należeli do romofonicznej ludności wołoskiej, która zamieszkiwała w wielu oazach we wschodniej Serbii, pomiędzy rzekami Morawą (Wielką i Południową) i Timokiem ${ }^{25}$. We wschodniej Serbii praktykowano, oprócz rodzinnego wypędzania owiec na pastwiska, również wiejskie stowarzyszanie pasterzy z jednej wsi, tzw. baczijanie/baczewanie ${ }^{26}$. Natomiast w zachodniej Serbii bogaci handlarze zakupywali pastwiska (serb. dželepi) i na sezon wynajmowali profesjonalnego pasterza, którego nazywano dżelepdżia_(serb. dželebdžija) ${ }^{27}$.

Ustanowienie nowych granic państwowych Serbii i Bułgarii na kongresie berlińskim położyło kres sezonowym migracjom pasterzy $\mathrm{z}$ terytoriów obu tych krajów w kierunku Morza Egejskiego. W roku 1873 z powodu budowy linii kolejowej, prowadzącej z Salonik do Skopje i Kosowskiej Mitrowicy (a później także z Salonik do Bitoli), znacznie zmniejszył się karawanowy transport towarów, którym zajmowali się arumuńscy pasterze. Zmusiło to Arumunów do zmiany swojego zajęcia (na karczmarstwo, handel i rzemiosło). Ustalenie granic państwowych Serbii

\footnotetext{
${ }^{25}$ Por. A. Sorescu-Marinković, Româii din Timoc astăzi. Flințe mitologice, Cluj-Napoca 2012.

${ }^{26}$ N. Pavković, Studije i ogledi iz pravne etnologije, u izdanju Srpskog genealoškog centra, Beograd 2014, s. 165-172.

${ }^{27}$ J. Cvijić, Balkansko poluostrvo, s. 225.
} 
(późniejszej Jugosławii), Bułgarii, Grecji i Albanii po wojnach bałkańskich i I wojnie światowej ostatecznie przerwało szlaki wcześniejszych sezonowych migracji pasterzy z rejonu centralnego w stronę Morza Egejskiego i Adriatyckiego. Pasterze z obszarów dzisiejszej Republiki Macedonii (ówcześnie należącej do Jugosławii) musieli szukać zimowych pastwisk w obrębie nowych granic państwowych, mając do wyboru ciepłe kotliny wokół miast Strumica, Gewgelia, Negotino, Sztyp, Koczani, Swety Nikole. $\mathrm{W}$ ten sposób arumuńscy pasterze całkowicie przywiązywali się do stałych terenów, tworzyli swoje wioski i zaczęli zajmować się rolnictwem. Równocześnie nasiliła się ich asymilacja ze społecznością słowiańsko-macedońską. Podobne procesy zachodziły również na obszarach Bułgarii, Albanii i Grecji ${ }^{28}$.

Rejon Wschodni. We wschodnim rejonie Półwyspu Bałkańskiego, na terytorium dzisiejszej Bułgarii, sezonowe migracje pasterzy także były ożywione do pierwszych dziesięcioleci XX wieku. Wykorzystywano pastwiska w pasmach górskich Riła, Rodopy i Bałkan. Bułgarscy i arumunscy pasterze wyruszali $\mathrm{z}$ tych pastwisk wraz ze swoimi stadami w kierunku ciepłych dolin i nizin, gdzie spędzali zimę, wypasając owce. Pasterze z północnych stoków górskich pasma Bałkan najczęściej zimowali na obszarze Dobrudży, dość blisko Morza Czarnego, oraz na równinie wokół Dolnego Dunaju, głównie w pobliżu miast Swisztow i Ruszczuk. W konsekwencji pasterze ze wschodniej części górskiego pasma Bałkan (okolica miasta Koteł) na stałe zamieszkali Dobrudżę. Pasterze, którzy użytkowali pastwiska na południowej stronie Bałkanu jak również na Sredniej Gorze, zimowali w kotlinach u podnóża gór lub w dolinie rzeki Marica, gdzie panuje zmienny śródziemnomorski klimat. Pasterze z Kopriwszticy na Sredniej Gorze uważali się za handlarzy pasterskich w czasie panowania tureckiego, a po wyzwoleniu tej części Bułgarii w drugiej połowie XX wieku na stałe zamieszkali (wcześniej rezygnując z pasterstwa) miasteczka u podnóża gór Bałkan: Złaticę, Pirdop, Kazanłyk, Starą Zagorę, Nową Zagorę, Płowdiw itd. Pasterze z pasma Rodopów zimowali na równinach na północnym wybrzeżu Morza Egejskiego lub w dolinie rzeki Marica, gdzie z czasem wielu z nich osiedliło się na stałe ${ }^{29}$.

${ }^{28}$ M. Zdraveva, G. Todorovski, Nomadskoto stočarstvo vo Makedonija vo XIX vek do 1918, Skopje 1997, s. 41-70; M. Luković, Balkanlarda Besicilerin Transhumance Hareketleri ve Balkan Savaşları'nın Besicilerin Mevsimsel Hareketlerine Etkisi / Transhumance Movement at Cattle Raisers in the Balkans and the Impact of Balkan Wars on Their Seasonal Moves, "History Studies. International Journal of History“ 2013, 5, 6, s. 41-58.

${ }^{29}$ J. Cvijić, Balkansko poluostrvo, s. 216-221. 


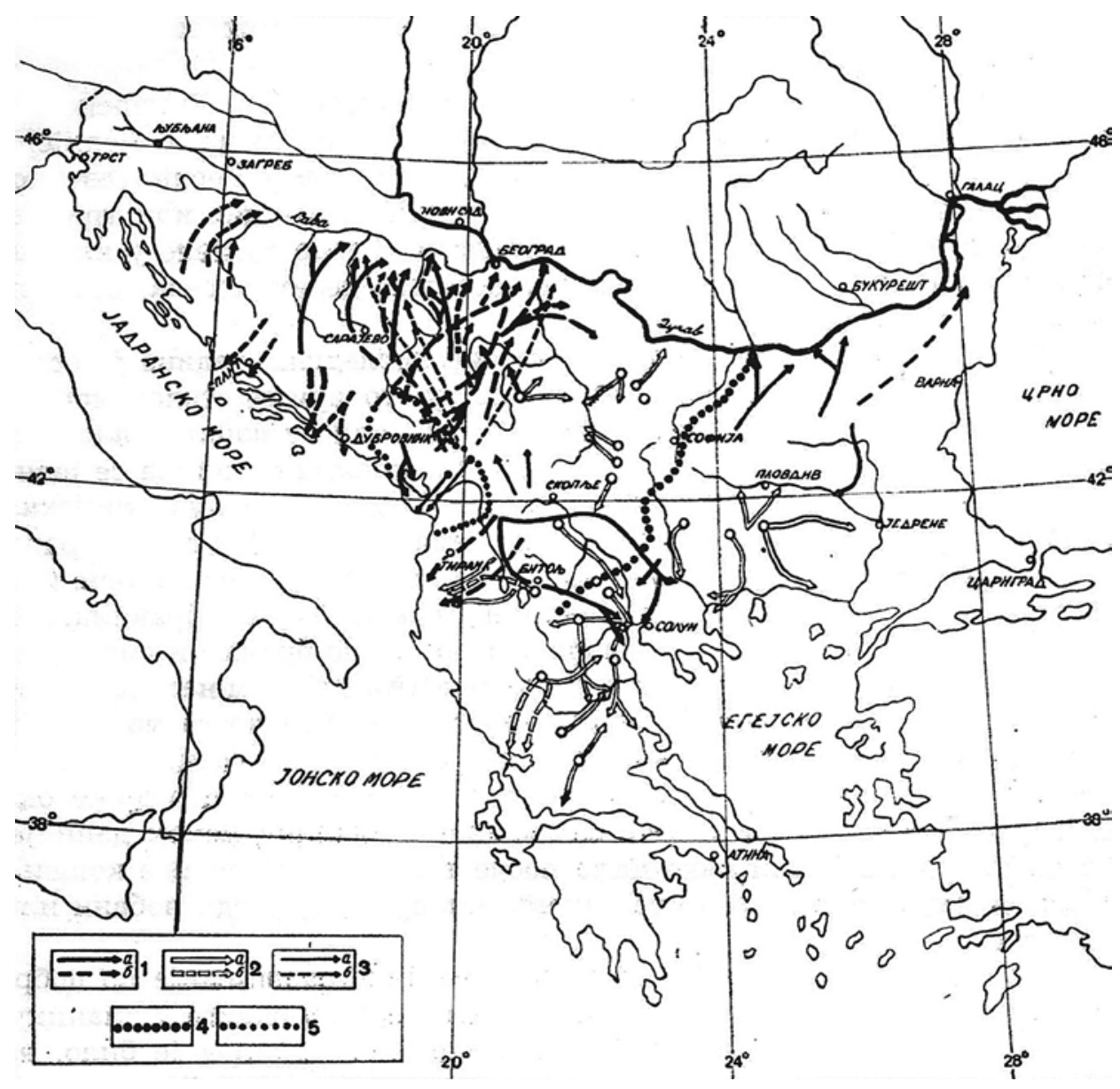

Ryc. 2. Sezonowe migracje pasterzy na Bałkanach: 1. a) migracje pasterzy południowosłowiańskich na początku XX wieku; b) wcześniejsze migracje pasterzy południowosłowiańskich; 2 . a) migracje arumuńskich pasterzy na początku XX wieku; b) wcześniejsze migracje pasterzy arumuńskich; 3. a) migracje albańskich pasterzy na początku XX wieku; b) wcześniejsze migracje pasterzy albańskich; 4. wschodnia granica rejonu, którą zamieszkiwały liczne rodziny (serb. zadruga) na początku XX wieku; 5. rejon, gdzie istniały plemiona (serb. pleme, alb. fis) do XIX wieku (J. Cvijić, Balkansko poluostrvo i južnoslovenske zemlje. Osnovi antropogeografije, Beograd 1966, s. 219)

\section{CHARAKTER SEZONOWYCH MIGRACJI PASTERZY NA BAŁKANACH}

Sezonowe wędrówki pasterzy na Bałkanach pomiędzy letnimi pastwiskami w wysokich górach i zimowymi pastwiskami w ciepłych, nadbrzeżnych nizinach i kotlinach bałkańscy historycy, geografowie, etnolodzy i podróżnicy długo klasyfikowali jako nomadyzm (koczownictwo). 
Jednak rozróżniali oni dwie sytuacje: 1) to, czy na letni wypas owiec wyruszała cała pasterska rodzina ze swoimi przenośnymi namiotami (jak to robili niektórzy arumuńscy pasterze aż do początku XX wieku); 2) czy może część pasterskiej rodziny zostawała na wsi, gdzie mieszkała na stałe i zajmowała się dodatkowymi pracami - rolnictwem, sadownictwem, rzemiosłem itp. (tak jak to robili albańscy, macedońscy, czarnogórscy, hercegowińscy, bułgarscy i inni bałkańscy pasterze). Dlatego wprowadzono rozróżnienie pomiędzy prawdziwym nomadyzmem i pótnomadyzmem. Po I wojnie światowej rumuńscy badacze (Theodor Capidan i inni) używali dwóch różnych terminów dla obu wymienionych rodzajów sezonowych migracji pasterzy na Półwyspie Bałkańskim: pierwszy rodzaj nazywano nomadyzmem, a drugi transhumancja ${ }^{30}$. Termin transhumancja zaczerpnięto z tradycyjnej włoskiej i hiszpańskiej terminologii pasterskiej. Pierwszy raz został użyty w roku 1780, następnie pojęcie to wprowadzono także we Francji ${ }^{31}$, a jeszcze później zaczęło być powszechnie używane przez autorów niemieckich i wielu innych z Europy Środkowej.

Jednak niektórzy współcześni historycy, badając sezonowe migracje pasterzy w ich wielowiekowej tradycji, odkrywają następujące fakty: 1) bałkańscy i karpaccy pasterze zawsze mieli ustalone miejsca pobytu (tj. letnie i zimowe pastwiska), gdzie wypasali swoje owce; 2) poruszali się ustalonymi szlakami, które są nadal aktualne, pomimo że sezonowe migracje są redukowane i modyfikowane ${ }^{32}$. Dlatego badacze coraz częściej odrzucają termin nomadyzm jako nieadekwatny w klasyfikacji sezonowych migracji pasterzy $\mathrm{w}$ dalszej i bliższej przeszłości na Bałkanach i w rejonie karpackim. Zamiast tego sugerują użycie terminu transhumancja / transhumancyjne pasterstwo. To pojęciowe rozgraniczenie zostało przyjęte w jugosłowiańskiej i serbskiej społeczności naukowej w ostatnich dziesięcioleciach ${ }^{33}$. W swoich pracach zwracam uwagę właśnie na terminy transhumancja / transhumancyjne pasterstwo, ponieważ uważam je za bar1925.

${ }^{30}$ Por. T. Capidan: Meglenoromănĭ. Memoriile Sectiunii literare. Ser. 3. Tom. 2. Mem., Cluj

${ }^{31}$ F. Braudel, Mediteranski svet u doba Filipa II, Beograd 2001, s. 99.

${ }^{32}$ Rumuński historyk prawa Liviu Marcu bardzo wyraźnie wskazał na różnicę między prawdziwym nomadyzmem i sezonowymi migracjami pasterzy na Bałkanach. Por. L. Marcu, Formes traditionnelles d'élevage pastoral et systèmes d'organisation chez les Vlaques balkaniques, [w:] Odredbe pozitivnog zakonodavstva i običajnog prava o sezonskim kretanjima stočara u jugoistočnoj Evropi. Zbornik radova sa međunarodnog naučnog skupa održanog 6. i 7. novembra 1975. u Beogradu, red. V. Čubrilović, Beograd 1976, s. 81-82.

${ }^{33}$ W Serbii użycie terminu transhumanca najchętniej sugerował mediewista Bogumil Hrabak, który problematyce średniowiecznych pasterzy poświęcił wiele badań, a szczególnie transhumancji w Hercegowinie; zob. B. Hrabak, Iz starije prošlosti Bosne $i$ Hercegovine, knj. II, Beograd 2003, s. 39-43. Termin transhumantno stočarstvo stosują też etnolodzy Nikola Pavković i Slobodan Naumović, por. N. Pavković, Studije i ogledi, s. 146. 
dziej odpowiednie w nazywaniu innych rodzajów sezonowych migracji pasterzy na Bałkanach w przeszłości i (w mniejszej formie) w dzisiejszych czasach.

\section{SPOŁECZNA ORGANIZACJA I STATUS PASTERZY WOŁOSKICH NA BAŁKANACH W ŚREDNIOWIECZU}

Wołosi (i Albańczycy) - średniowieczni pasterze na Bałkanach. Dzisiejsza historiografia więcej uwagi poświęca gospodarczym oraz agrarnym aspektom średniowiecznej historii ${ }^{34}$. Wywnioskowano, że w średniowieczu na Półwyspie Bałkańskim istniały dwa rodzaje pasterstwa. Jeden był autochtoniczny: były to właśnie sezonowe migracje pasterzy z owcami i kozami między letnimi pastwiskami w górach (serbskie średniowieczne źródła podają letišta/planine) i zimowymi w ciepłych nizinnych i nadmorskich obszarach (serbskie zimišta/zimovišta). Do tego rodzaju pasterzy należała rdzenna ludność Bałkanów, zajmująca się zawodowo jedynie pasterstwem i to jeszcze przed osiedleniem się Słowian. Z czasem ludność słowiańska i pozostałe grupy etniczne na Bałkanach przyjęły ten rodzaj pasterstwa. Drugim rodzajem pasterstwa była hodowla dużej i małej trzody (krowy, świnie, owce, kozy), którą zajmowali się rolnicy różnego pochodzenia etnicznego, ale to nie było ich jedyne zaję$\mathrm{cie}^{35}$. Pozycja pasterzy i rolników w systemie feudalnym na terenach średniowiecznych państw bałkańskich była zróżnicowana. Ponieważ status pasterzy zawsze był lepszy ze względu na obowiązki feudalne, istniała stała tendencja przyjmowania go także przez rolników.

W średniowiecznych źródłach bałkańskich najczęściej pojawiają się Wołosi (Vlasi), określani mianem pasterzy bałkańskich, a znacznie rzadziej Albańczycy (Arbanasi). W tekstach bizantyjskich pisarzy (Jan Skylitzes, Katakalon Kekaumenos, Anna Komnena, Niketas Choniates i inni) odnaleźć można wiele informacji o Wołochach. Wołosi w historycznych źródłach pierwszy raz zostają wspomniani w dziele Jana Skylitzesa, pochodzącym z roku 976 i odnoszącym się do Wołochów z rejonu dzisiejszej północno-zachodniej Grecji. Kekaumenos w swoim dziele Strategikon podaje najstarsze dane (z roku 1066) o sezonowych migracjach pasterzy mię-

\footnotetext{
${ }^{34}$ Por.: D. Angelov, Agrarnite odnošenija v severna i sredna Makedonia prez XIV vek, Sofia 1954; M. Blagojević, Zemljoradnja u srednjovekovnoj Srbiji, Beograd 1973; R. Katić, Stočarstvo srednjovekovne Srbije, Begrad 1978; J. Mrgić, Zemlja i ljudi: Iz istorije životne sredine zapadnog Balkana, Beograd 2013.

${ }^{35}$ M. Luković, Stočarska privreda kao činilac oblikovanja narodne kulture Srba, [w:] Narodna kultura Srba između Istoka i Zapada, red. L. Radenković, Beograd 2014, s. 49-50.
} 
dzy ciepłą kotliną Tesalii i wysokimi i chłodnymi obszarami w górach Bułgarii ${ }^{36}$ (mowa o ówczesnym bizantyńskim temie Bułgaria z centrum w Skopje). Geneza sezonowych migracji pasterzy na Bałkanach bez wątpienia sięga prehistorii. Sezonowe migracje Wołochów zanotowano w roku 1285 $\mathrm{w}$ Tracji ${ }^{37}$ oraz na innych obszarach Bałkanów w różnych okresach średniowiecza $^{38}$. Współcześni badacze stwierdzaja że o pasterzach z późnego średniowiecza zachowanych jest o wiele więcej dokumentów w zachodniej części Półwyspu Bałkańskiego niż we wschodniej. Potwierdzają to przede wszystkim dokumenty zgromadzone $\mathrm{w}$ archiwach miast na wschodnim wybrzeżu Adriatyku: w Dubrowniku, Kotorze, Splicie, Zadarze, Trogirze (a także Wenecji) ${ }^{39}$. Nieco mniej informacji znajduje się na terenie dzisiejszej Chorwacji, wchodzącej w średniowieczu w skład królestwa Węgier, w urbarzach, które zawierają pisemne zobowiązania ludności względem własności feudalnej ${ }^{40}$. Istotne informacje o średniowiecznych Wołochach ujawniają darowizny, które władcy i feudałowie nadawali prawosławnym klasztorom / monastyrom na Bałkanach w XII-XV wieku ${ }^{41}$.

Średniowieczni Wołosi zajmowali się również hodowlą koni, ponieważ były im one niezbędne do wykonywania prac związanych z pasterstwem jak również do wywiązywania się z obowiązków feudalnych. Konie służyły do transportu różnych towarów, przede wszystkim soli z odległych warzelni, głównie nadmorskich. Sól była konieczna przy hodowli bydła, znajdowała zastosowanie spożywcze, a także była transportowana na zamówienie panów feudalnych i monastyrów. Z czasem Wołosi zaczęli zajmować się transportem innych rodzajów towarów w interesie zawodowych handlarzy, a coraz częściej i w swoim własnym. Z podstawowych działalności - pasterstwa i transportu - wykształcały się stopniowo również inne zajęcia wołoskich średniowiecznych pasterzy na Bałkanach. Co-

${ }^{36}$ G. Ostrogorski, F. Barešić, Vizantijski izvori za istoriju naroda Jugoslavije I, Beograd 1966, s. 70-79, 213-216.

${ }^{37}$ K. Jireček, Geschichte der Serben, Bd 2, Gotha 1918, s. 123.

38 Por. M. Gyöni, La Transhumance des Vlaques Balkaniques au Moyen Age, „Byzantoslavica" 1951, 12, s. 29-42.

39 S. Dragomir, Vlahii din Serbia în sec. XII-XV, "Anuarul Institutului de Istorie Națională", 1921/1922, s. 279 -299; P. Skok, Iz rumunske literature o balkanskim Vlasima. IIIIV, "Glasnik Skopskog Naučnog Društva” 1928, 2, 3-4, s. 300-301.

${ }^{40}$ N. Klaić, Izvori za hrvatsku povijest do 1526. godine, Zagreb 1972, s. 229-235, 253-254, 278-281, 302-303, 330-338.

${ }^{41}$ Normami serbskich darowizn monastycznych, w których pojawia się Zakon Vlahom, szczególnie zajmował się mediewista Miloš Blagojević. Zob. więcej w: M. Blagojević, Posebni zakoni na manastirskim vlastelinstvima, [w:] Srednjovekovno pravo u Srba u ogledalu istorijskih izvora. Zbornik sa naučnog skupa održanog 19-21. marta 2009, red. S. Ćirković, K. Čavoški, Beograd 2009, s. 21-33. 
raz częściej pojawiali się oni w roli handlarzy, rzemieślników, rolników, żołnierzy, drobnych feudałów. W ten sposób zmieniał się ich rodzimy status społeczny, a równocześnie i pierwotny charakter etniczny.

Po II wojnie światowej coraz prężniej rozwija się bałkanistyka (bałkanologia) jako odrębna dyscyplina naukowa. Już pół wieku temu skonstatowano, że średniowieczni Wołosi przedstawiają jedno z głównych zagadnień owej dyscypliny. Badanie tego problemu wpływa na analizę i zrozumienie szeregu innych zagadnień. Ponadto w Jugosławii (a także w państwach postjugosłowiańskich), Bułgarii, Albanii i Grecji rozwijająca się osmanistyka dostarczyła mnóstwo nowych informacji o Wołochach ${ }^{42}$. Stąd mediewiści coraz częściej korzystali z dokonań osmańskich badaczy, szczególnie w celu wyjaśnienia charakteru wołoskich instytucji i statusu pasterzy ${ }^{43}$. Średniowieczne dokumenty osmańskie wykazuja, że sezonowe migracje pasterzy były nasilone w tych okresach, kiedy sytuacja polityczna była stabilna i kiedy konkretnemu państwu przypadało rozległe terytorium. Jednak od pierwszej wzmianki o Wołochach $w$ drugiej połowie $X$ wieku do pierwszych dziesięcioleci XVI wieku - kiedy Imperium Osmańskie znajdowało się w okresie ekspansji, poszerzając swój zasięg w kierunku Panonii - upłynęło więcej niż pięć stuleci. Zrozumiałe jest, że $\mathrm{w}$ tak długim okresie na całym terenie Bałkanów miały miejsce złożone procesy zmian statusowych, społeczne dyferencjacje i etniczne przemiany Wołochów. Te procesy w niektórych rejonach Półwyspu Bałkańskiego miały swój specyficzny charakter. Na początku panowania tureckiego termin Wołoch stracił swój etniczny sens, całkowicie przyjmując znaczenie zawodowego pasterza, któremu przypadał określony status społeczny i polityczny ${ }^{44}$.

Katun - podstawowa jednostka pasterskiego społeczeńst wa. Mimo że ciągle trwały sezonowe migracje, Wołosi w średniowieczu zostali włączeni do feudalnego systemu państw na Bałkanach: Bizancjum, państwa bułgarskiego, serbskiego, bośniackiego, węgiersko-chorwackiego jak i do Republik Raguzy (Dubrownickiej) i Weneckiej. Te chrześcijańskie

${ }^{42}$ Efekty rozwoju serbskiej mediewistyki zawarte są w obszernej pracy: Leksikon srpskog srednjeg veka, red. S. Ćirković, R. Mihaljčić, Beograd 1999. O rozwoju osmanistyki w okresie jugosłowiańskim i postjugosłowiańskim zob. więcej w: R. Smajić, Pravci razvoja osmanistike u jugoslovenskom i postjugoslovenskom periodu, [w:] Naučno djelo Branislava Đurđeva. Zbornik radova sa međunarodnog okruglog stola održanog u Sarajevu 4. decembra 2009, red. Dž. Juzbašić, Sarajevo 2010, s. 93-100.

${ }^{43}$ Por. V. Kursar, Being an Ottoman Vlach: on Vlach Identity (Ies), Role and Status in Western Parts of the Ottoman Balkans (15 th $-18^{\text {th }}$ Centuries), "OTAM. Ankara Üniversitesi Osmanl Tarihi Araştırma ve Uygulama Merkezi Dergisi" 2013, 24, 34, s. 115-161.

${ }^{44}$ E. Miljković, Vlasi u domaćoj istoriografiji (1960-2010), „Braničevski Glasnik” 2010, 7, s. 5-22. 
państwa nie rozwijały się identycznie, w każdym z nich funkcjonowała nieco inna forma feudalizmu. Wpłynęło to na status Wołochów. Średniowieczne źródła (oraz te z wczesnego okresu osmańskiego) na Bałkanach wykazuja że wołoscy pasterze stworzyli swój własny system. W źródłach często wzmiankuje się o katunach Wołochów, w niektórych dokumentach można znaleźć informację również o katunach Albańczyków. Katun i jego cała organizacja wyrażała specyficzny status Wołochów w ramach ludności zależnej w systemie feudalnym. Stąd katun średniowiecznych Wołochów na Bałkanach interesował współczesnych badaczy, ale mimo to na długo pozostał niewyjaśnionym zagadnieniem.

Po wielu próbach podjętych jeszcze w XIX w. badacze w drugiej połowie XX wieku wyjaśnili charakter i funkcje średniowiecznego katuna, dochodząc do wniosku, że w średniowiecznych warunkach feudalnych tylko stabilna organizacja mogła zapewnić realizację cyklicznych sezonowych migracji Wołochów od letnich do zimowych pastwisk jak również spełnienie ich obowiązków w stosunku do feudalnych władców. Tak więc katun średniowiecznych Wołochów uważany jest dziś za korporacyjnq organizacje życia gospodarczego i społecznego ówczesnych sezonowych pasterzy, o stabilnym charakterze ${ }^{45}$. Była to podstawowa jednostka społeczeństwa pasterskiego, wywodząca się z rodowej formacji. Katun liczył 20-50 rodzin, w których czasami pojawiali się krewni również z linii żeńskiej (siostrzeńcy, zięciowie). Po jakimś czasie można ich było rozdzielić na nowe katuny.

Na czele katuna stał wódz, który odpowiadał za organizację działalności pasterskiej, a także za wypełnianie zobowiązań podatkowych oraz wszystkich innych obowiązków. Wódz wybierany był przez samorząd wśród członków katuna. Katuni nazywani byli imionami swoich wodzów, np. katun Vuka Radiczevicia ${ }^{46}$. Na zachodnich terenach Bałkanów przywódcy katunów często byli nazywani katunarami (serb. katunar). Pod wpływem feudalizmu bizantyjskiego w serbskim średniowiecznym państwie w XIV wieku władza zaczęła wybierać wodzów katuna, których

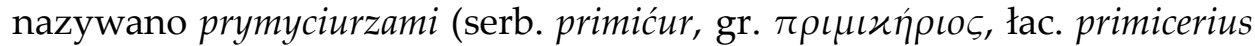
$<$ primus cerae). W centralnych i zachodnich rejonach władza mianowała

${ }^{45}$ M. Filipović, Katun u našoj istoriografiji. Struktura i organizacija srednjovekovnih katuna, w: Simpozijum o srednjovjekovnom katunu održan 24. i 25. novembra 1961. g., red. M. Filipović, Sarajevo 1963, s. 9-14, 17, 39-41, 45-112, 118-120, 141-142, 169.

${ }^{46} \mathrm{Na}$ sympozjum na temat „Średniowieczny katun”, które odbyło się w Sarajewie w 1961 r., mediewistka Desanka Kovačević przytoczyła wiele informacji o średniowiecznym katunie i średniowiecznych Wołochach z Archiwum Dubrownickiego. Zob. więcej w: D. Kovačević, Srednjovjekovni katun po dubrovačkim izvorima, [w:] Simpozijum o srednjovjekovnom katunu održan 24. i 25. novembra 1961. g., red. M. Filipović, Sarajevo 1963, s. 121-140, 169. 
na przełożonych kniaziów, ale ta praktyka nie była konsekwentnie stosowana na zachodnich obszarach Bałkanów. Na czele grupy składającej się z kilku katunów stał kniaź, który zawsze był jednym z katunarów. Odpowiadał on za porządek w katunie, którym dowodził, sprawował również funkcję sądowniczą. $W$ ten sposób pełnił też rolę łącznika pomiędzy samorządem katuńskim a władzą państwową. Władza mianowała także wojewodów w większych zbiorowiskach pasterzy, którzy również wybierani byli z szeregu katunarów. Wojewodowie odpowiadali za mobilizację żołnierzy w zbiorowościach katunów i dowodzili w czasie wojny ${ }^{47}$. Oprócz tego w XV wieku coraz bardziej rozwijała się instytucja zgromadzenia (serb. zbor, skupština $)^{48}$. Zdarzało się to w okolicznościach słabnięcia władzy państw chrześcijańskich i rosnącego wpływu Imperium Osmańskiego na wydarzenia polityczne na Bałkanach. Na zgromadzeniach wodzowie katunów i kniaziowie wydawali decyzje mające istotne znaczenie dla katunów ${ }^{49}$. Tak uformowana organizacja pasterzy (katuńska organizacja) chroniła społeczna autonomie pasterskiej ludności w ramach systemu feudalnego państw chrześcijańskich na Bałkanach ${ }^{50}$.

W średniowiecznych państwach bałkańskich prawo zwyczajowe regulowało kwestie związane z działalnością pasterską i życiem pasterzy. O obowiązkach podatkowych i statusie najwięcej dowiadujemy się z darowizn nadawanych klasztorom prawosławnym (monastyrom). Można zauważyć, że większość obowiązków Wołochów niczym się nie różniła. Wołosi dzielili się na dwie podstawowe kategorie: żołnierzy (serb. vojnici) i cielatorów (serb. ćelatori) ${ }^{51}$. Było to zależne m.in. od kategorii i statusu majątkowego. Cielatorzy stanowili liczniejszą grupę, ale byli biedniejsi od warstwy żołnierskiej. Wołosi, którzy należeli do żołnierzy, jako jeźdźcy zaliczani byli do sił zbrojnych władców. Jednak bez względu na różnice żołnierze i cielatorzy uczestniczyli w karawanowym transporcie soli i innych towarów na potrzeby monastyru lub pana feudalnego.

Wołosi wszystkie swoje zobowiązania podatkowe spełniali w ramach katunu. Tak więc katun był także jednostką skarbową. Najważniejsze zobowiązania podatkowe realizowano $\mathrm{w}$ naturze. Podatek miał dwie for-

\footnotetext{
${ }^{47}$ M. Blagojević, Vlaški knezovi, primićuri i čelnici u državi Nemanjića i Kotromanića (1314. vek), [w:] Spomenica Milana Vasića, red. R. Mihaljčić, Banja Luka 2005, s. 43-75.

${ }^{48}$ S. Ćirković, Rabotnici, vojnici, duhovnici. Društva srednjovekovnog Balkana, Beograd 1997, s. 336-340.

${ }^{49}$ Przytaczając i komentując obszerną literaturę, o całej problematyce szczególnie pisałem w: Katun a katunská organizace středověkých Vlachů v centrálních a západních oblastech Balkánu, „Slovanský Přehled“ 2013, 5, s. 21-60.

${ }^{50}$ M. Vasić, Knežine i knezovi timarlije u Zvorničkom sandžaku u XVI vijeku, „Godišnjak Istoriskog Društva Bosne i Hercegovine“" 1959, 10, s. 248-249.

${ }^{51}$ M. Blagojević, Posebni zakoni na manastirskim vlastelinstvima, s. 22-32.
} 
my: była to wielka dziesięcina (serb. veliki desetak) lub mała dziesięcina (serb. mali desetak). Ten system rozwinął się pod wpływem Bizancjum ${ }^{52}$. Wielka dziesięcina obejmowała jedną dziesiątą ze zwierząt hodowlanych każdego gospodarstwa w katunie oraz przekazywanie wełnianych tkanin. Składanie wielkiej dziesięciny zwalniało z wykonywania innych obowiązków. Wielka dziesięcina mogła zostać zamieniona na małą. W takim przypadku gospodarstwo przekazywało jedną owcę z jagnięciem i jedną jałową owcę oraz było obarczone różnymi pracami, takimi jak wypasanie klasztornych owiec, obróbka wełny, produkcja wyrobów wełnianych itd.

Wołosi swoje owce i kozy wypasali na górskich i zimowych pastwiskach, które pierwotnie były w posiadaniu władcy, ale stopniowo przechodziły w ręce feudałów, monastyrów i kościołów. Za korzystanie z zimowych i górskich pastwisk Wołosi wnosili opłaty (serbskie źródła podają travnina, travarina, także planiniotiko). Zgodnie z prawnym zwyczajem wysokość tej opłaty zależała od jakości pastwiska i jakości owiec, ale średnio wnosili dwie-trzy owce ze stada liczącego 100 owiec. Wędrówki pasterzy między zimowymi i letnimi pastwiskami były regulowane starym prawem zwyczajowym (przejętym z Bizancjum), a w XIV wieku została wprowadzona norma prawna ${ }^{53}$.

Kiedy rozpoczęła się inwazja osmańska na Bałkanach, już od końca XIV wieku, pojawił się nowy rodzaj podatku, „,wołoski dukat”, który zastąpił dziesięcinę ze zwierząt hodowlanych, ale głównie tam, gdzie były duże skupiska ludności wołoskiej. Pojawienie się tego podatku związane było z wprowadzeniem haraczu - obowiązkowej opłaty wymuszanej na krajach chrześcijańskich lub niezależnych obszarach feudalnych przez państwo osmańskie. Roczny haracz (który zwykle wynosił dziesiątki tysięcy dukatów) nałożony był na ludność zamieszkującą terytorium wasalne, więc każde wołoskie gospodarstwo płaciło „od ogniska”, „od dymu” jednego dukata ${ }^{54}$.

Średniowieczne dokumenty z XIV i z pierwszej połowy XV w. świadczą o tym, że w niektórych częściach Półwyspu Bałkańskiego proces przemiany Wołochów w rolników był zaawansowany. Oznaczało to, że tworzyli swoje wsie (najczęściej tam, gdzie przebywali zimą ze swoją trzodą) lub osiedlali się w wioskach, które już zamieszkiwali rolnicy. Ten proces przeważnie określa się terminem sedentaryzacji. Niektóre średniowieczne dokumenty mówią o „katunach z miedzą” i o „katunach bez miedzy”. Po-

${ }^{52}$ M. Cvetković, Uključivanje Slovena i Vlaha u provincijske organizacije na jugu Balkana do XI veka. Sličnosti i razlike, "Zbornik Radova Vizantološkog Instituta“ 2012, s. 19-41.

${ }^{53}$ Leksikon srpskog srednjeg veka (hasło travnina), s. 736-737.

${ }^{54}$ B. Hrabak, Čelnici stočarskih zajednica u istočnoj Hercegovini u XIII-XIV veku, [w:] Zbornik za istoriju Bosne i Hercegovine, 2, red. M. Ekmečić, Beograd 1997, s. 139-172. 
nadto stopniowo zanikał zwyczaj nazywania katuna imieniem jego przywódcy, a Wołosi coraz częściej określali się według miejsca zamieszkania (np. „katun in Biella in Drobgnaci” $)^{55}$.

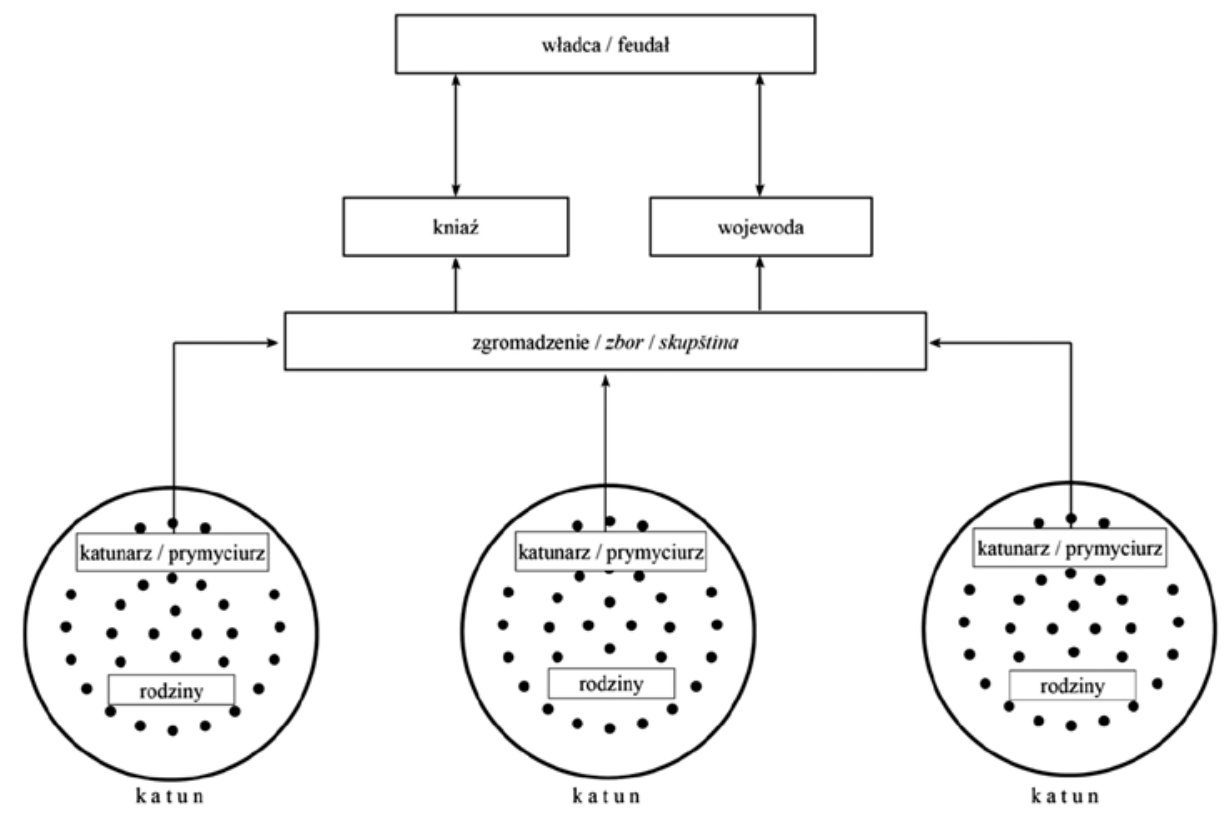

Ryc. 3. Katun i katuńska organizacja średniowiecznych Wołochów (M. Luković, Knežinska i plemenska samouprava kod Srba: poreklo institucija, „Naša Prošlost“ 2013, 14, s. 29).

\section{ZMIANY STATUSU I SPOSOBU ORGANIZACJI MIGRACJI SEZONOWYCH W OKRESIE OSMAŃSKIM}

Status wołoski ('âdet-i Eflakiye). Podboje osmańskie w drugiej połowie XIV i w XV wieku były przyczyną wielkich migracji ludności na Bałkanach i w krajach sąsiadujących jak również wędrówek Wołochów w wielu kierunkach. Państwo osmańskie rozprzestrzeniało się na dużym terytorium Półwyspu Bałkańskiego, później także w regionie karpackim oraz przez krótszy okres na obszarze Panonii. Sprzyjało to sezonowym migracjom pasterzy na dłuższych szlakach i ogólnemu rozwojowi tradycyjnego pasterstwa ${ }^{56}$. Jednak ekspansja turecka rozpowszechniła na Bałka-

${ }^{55} \mathrm{O}$ tym złożonym i długotrwałym procesie pisało wielu autorów, którzy zajmowali się średniowiecznymi Wołochami. Zob. D. Kovačević, Srednjovjekovni katun po dubrovačkim izvorima, s. 121-140, 169.

${ }^{56}$ A. Matkovski, op. cit., s. 16. 
nach szczególny typ feudalizmu - system spahisko-tymarski ${ }^{57}$. Pojawiło się wtedy pytanie, w jaki sposób Turcy mają zintegrować Wołochów (tur. Eflak/Eflakân) w tym systemie.

Kiedy Osmanowie (Turcy osmańscy) ${ }^{58}$ całkowicie podbili dane terytorium (likwidując jego poprzedni status wasalny), natychmiast tworzyli sandżak (tur. sancak), który był podstawową jednostką administracyjno-wojskową w Imperium Osmańskim ${ }^{59}$. Zaraz potem przeprowadzali spis ludności różnych grup zasiedlających zdobyty obszar, ich własności i dochodów w celu uzgodnienia zobowiązań podatkowych. W ten sposób powstawały osmańskie księgi podatkowe - deftery (tur. defteri). Deftery sandżaków osmańskich w Europie, które pochodzą z XV i XVI wieku, na ogół są znane i częściowo opublikowane. Te wczesne deftery zawierają też krótkie przepisy (tur. kânûn), które odnoszą się do zobowiązań podatkowych i dotyczą ludności określonego sandżaku, w tym także Wołochów. Później pojawiły się skodyfikowane zbiory sułtańskich przepisów (tur. kânûnnnâme), które również były cytowane w defterach. Historycy już dawno ustalili, że Osmanowie właściwie przejęli normy i zwyczaje prawne, które obowiązywały Wołochów w poprzednich państwach ${ }^{60}$.

Publikacja defterów i analiza różnych aspektów systemu Imperium Osmańskiego na Bałkanach w ciągu kilku ostatnich dekad w dawnej Jugosławii i krajach postjugosłowiańskich umożliwiły lepsze spojrzenie na pozycję i organizację Wołochów jako pasterzy w ramach ustroju osmańskiego. Deftery wykazuja że państwo tureckie dopiero w połowie $\mathrm{XV}$ wieku zdefiniowało wołoski status pasterskiej ludności (tur. 'âdet-i Eflakiye). Nastąpiło to po zdobyciu Konstantynopola (1453), kiedy Osmanowie definitywnie rozpoczęli podbój terytoriów Bałkanów na północ i zachód od Skopja, tj. pozostałości państwa serbskiego i bośniackiego. Przed tym Turcy na podbitych terytoriach we wschodnich i centralnych częściach Półwyspu Bałkańskiego osiedlali Juruków (tur. Yürük), czyli no-

${ }^{57}$ Por. N. Flipović, Pogled na osmanski feudalizam, „,Godišnjak Istoriskog Društva Bosne i Hercegovine" 1952, 4, s. 102-113.

${ }^{58}$ Terminów Osmanowie i Turcy osmańscy używam zamiennie, ale wolę określenie Osmanowie.

${ }^{59} \mathrm{O}$ systemie administracyjno-terytorialnych jednostek w Imperium Osmańskiego w „epoce klasycznej“ (1300-1600) zob. więcej w: H. İnalcik, Osmansko carstvo. Klasično doba. Beograd 1974; A. Stojanovski, Administrativno-teritorijalnata podelba na Makedonija pod osmanskata vlast do krajot na XVII vek, "Glasnik na Institutot za Nacionalna Istorija“ 1973, 2, s. 129-145; H. Šabanavić, Bosanski pašaluk, Sarajevo 1982; O. Zirojević, Tursko vojno uređenje u Srbiji 1459-1683, Beograd 1974.

${ }^{60} \mathrm{M}$. Begović, Tragovi našeg srednjovekovnog prava u turskim pravnim spomenicima, „Istoriski Časopis“ 1951/1952, 3, s. 67-84; H. İnalcik, Od Stefana Dušana do Osmanskog carstva, „Prilozi za Orijentalnu Filologiju“ 1953, 3, 1, s. 23-55. 
madzkich pasterzy z Azji Mniejszej, którzy mieli specjalny status społeczny ${ }^{61}$. Jeśli porównać deftery pojedynczych sandżaków $\mathrm{z}$ drugiej połowy XV wieku i z pierwszych dekad XVI wieku, widzi się duże podobieństwa w obowiązkach Wołochów w północnych i zachodnich regionach Półwyspu Bałkańskiego - w sandżakach, które graniczyły z Królestwem Węgier: Widyńskim, Smederewskim, Zworniczkim, Hercegowińskim. W defterach wyraźnie ukazane są pieniężne i naturalne zobowiązania ludności, której przysługiwał wołoski status. Wszystkie te obowiązki naturalne były przeliczane na osmańskie drobne, srebrne pieniądze nazywane akczami/ asprami (tur. $a k c ̧ e$ ). Było to możliwe, ponieważ w Imperium Osmańskim istniał scentralizowany system monetarny i skarbowy.

Podstawowym pieniężnym zobowiązaniem podatkowym Wołochów było płacenie filurii (tur. resm-i filuri). Każde wołoskie gospodarstwo (tur. hane) płaciło jedną złotą monetę (tur. filori, z wł. florin, złatnik, złotnik lub zołotnik $)^{62}$. Filurie zawsze opłacano $w$ ramach katuna, który reprezentował jednostkę skarbową. Jako że katun liczył 20-50 gospodarstw, filuria wynosiła 20-50 złotników za katun. Płacenie filurii oznaczało, że dana ludność posiada wołoski status. Każdy katun miał dodatkowe mniejsze zobowiązania w naturze (owce, ser, powróz, uździenica, namiot z koziej sierści dla wojska). Ponadto co piąte lub dziesiąte gospodarstwo (w zależności od sandżaka) wybierało jednego jeźdźca (tur. eşkünci) dla wojska osmańskiego na wypadek wojny ${ }^{63}$.

Taka pozycja Wołochów była o wiele lepsza od statusu rolników - raji (tur. re'âyâ), którzy mieli większe obowiązki ${ }^{64}$. $Z$ tego powodu we wczesnym okresie osmańskim istniała tendencja do przyjmowania statusu wołoskiego przez rolników. W ramach sandżaku Wołosi nie byli podporządkowani drobnym feudałom - spahisom (tur. sipâhî), którzy za życia otrzymywali najmniejsze osmańskie lenno - timar (tur. tîmâr). Wołosi bezpośrednio podlegali dowódcy sandżaka - sandżak-bejowi (turecki sancakbey). Dochody z filurii należały do skarbu państwa, ale w niektórych

${ }^{61} \mathrm{H}$. İnalcik, The Yürüks: their Origins, Expansion an Economic Role, [w:] The Midle East and the Balcans under Ottoman Empire. Esseys on Economy and Society, Bloomington 1993, s. 117.

${ }^{62} \mathrm{O}$ podatku filuria szczególnie patrz: H. İnalcik, Filori, [w:] Diyanet Vakfi İslam Ansiklopedisi, vol. 13, Istanbul 1996, s. 106-107.

${ }^{63}$ A. S. Aličić, Poimenični popis Sandžaka vilajeta Hercegovina, Sarajevo 1985, s. V, IX, 26; D. Bojanić, Turski zakoni i zakonski propisi iz XV i XVI veka za smederevsku, kruševačku i vidinsku oblast, Beograd 1974, s. 15-16, 27, 30, 33; V. Kursar, Being an Ottoman Vlach, s. 123-136.

${ }^{64} \mathrm{~W}$ systemie osmańskim termin raja $\mathrm{w}$ istocie oznaczał całą produktywną ludność, która płaciła podatek państwu, ale termin ten często jest używany w węższym znaczeniu dla określenia ludności rolniczej. Por. A. Aličić, Katastarski popis Elajeta Bosna. Opširni katastarski popis za oblast Hercegovu iz 1585. godinu (Sveska I), Sarajevo 2014, s. VIII-X. 
sandżakach przypadały (w całości lub częściowo) również sandżak-bejowi. Wołosi we wczesnym okresie osmańskim byli rekrutowani w szeregi oddziałów wojskowych i półwojskowych, takie jak na przykład wojnukowie (tur. voynuk) czy martolosy (tur. martolos) lub jako strażnicy mostów i wąwozów (tur. derbedci). Przynosiło im to znaczne przywileje i obniżenie podatków. Szczególnie uprzywilejowani byli wołoscy przywódcy, którzy czasami otrzymywali lenno (timar), nie musząc przechodzić na islam

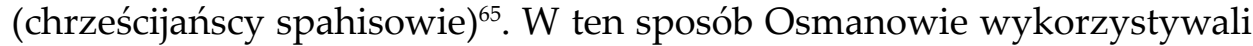
Wołochów do umocnienia swojego panowania na nowo zdobytych terenach i likwidacji pozostałości klasy feudalnej na podbitych chrześcijańskich ziemiach.

Wymienione obowiązki nie hamowały Wołochów w ich sezonowych migracjach. Wczesne osmańskie deftery wskazują miejsca, gdzie Wołosi latem wypasali owce, i miejsca, gdzie spędzali zimę. Defter bośniackiego sandżaka zawiera informację, że z końcem XVI wieku ożywiły się sezonowe migracje pasterzy na dłuższych szlakach. Jednak $\mathrm{w}$ drugiej połowie XV i w przeciagu XVI wieku proces fundamentalnej transformacji obejmuje wołoski katun, co zmienia jego pierwotny charakter i rolę. Ten proces dokonuje się na dwa sposoby: 1) jako terytorializacja katuna; 2) jako transformacja katuna w tajfę.

Terytorializacja katuna i ustanowienie nowych jednostek sam or ząd ow y ch. Jak już wcześniej wspomniano, w systemie migracji sezonowych średniowieczni Wołosi długo nie mieli swoich stałych osad. Ale z czasem miejsca zimowych pobytów przekształciły się w ich trwałe osady - wsie. Zdarzało się to w różnych historycznych okoliczności, najpierw $\mathrm{w}$ ramach włości monastycznych. Tym samym rozpoczął się długotrwały proces wiążący pasterskie katuny z określonym terenem, który był już zamieszkany przez ludność rolniczą. Proces ten nazwano terytorializacja katunów $w^{66}$. W ten sposób dochodziło do mieszania pasterzy z zastaną ludnością rolniczą poprzez wzajemny wpływ na gospodarkę i styl życia. Proces terytorializacji katuna zakończył się w XV wieku, kiedy Imperium Osmańskie całkowicie zawładnęło pozostałościami państw serbskiego i bośniackiego, popadając w coraz częstsze w konflikty z Królestwem Węgier.

${ }^{65}$ N. Filipović, Islamizacija Vlaha u Bosni i Hercegovini u XV i XVII vijeku, [w:] Simpozijum: Vlasi u XV i XVI vijeku (Sarajevo, 13-16 XI 1973). Referati i saopštenja. Diskusija, „Radovi ANUBIH“, 73, red. D. Kovačević-Kojić, Sarajevo 1983, s. 139-148.

${ }^{66}$ B. Đurđev, Teritorijalizacija katunske organizacije do kraja XV vijeka (katun - knežina - pleme), w: Simpozijum o srednjovjekovnom katunu održan 24. i 25. novembra 1961. g., red. M. Filipović, Sarajevo 1963, s. 143-169. 
Z powodu konfliktów wojennych wiele terenów rolniczych na północy i zachodzie Półwyspu Bałkańskiego opustoszało. Tym samym Osmanowie jeszcze $\mathrm{w}$ drugiej połowie $\mathrm{XV}$ wieku masowo osiedlali wołoskich pasterzy z wysokich gór na opuszczonych obszarach równinnych ${ }^{67}$. Były to tereny położone na południe od Sawy i Dunaju (dzisiejsza centralna Serbia, północna Bośnia i północna Bułgaria), ale także niektóre opuszczone kotliny i doliny rzeczne w Hercegowinie i w Bośni. W ten sposób ludność pasterska pojawiła się na obszarach o innych cechach geograficznych, gdzie nie było warunków do pasterskich migracji sezonowych. Katun został pozbawiony swojej wcześniejszej funkcji gospodarczej: organizowania sezonowych migracji pasterzy. Wkrótce stracił także swoją rolę jednostki skarbowej.

Znaczenie organizacji Wołochów w systemie tureckim gwałtownie spadło po bitwie pod Mohaczem (1526) i podbiciu Królestwa Węgier, tzn. po ekspansji tureckiej na Europę Środkową w latach trzydziestych i czterdziestych XVI wieku. Granice Imperium Osmańskiego były wtedy przesunięte daleko na północ, a przygraniczne sandżaki, leżące na południe od Sawy i Dunaju (Smederewski, Bośniacki, Widyński), traciły strategiczne znaczenie. Doprowadziło to do unieważnienia przywilejów wołoskich wodzów i zrównania statusu pasterzy ze statusem rolników - rajy ${ }^{68}$. Wołosi przekształceni $\mathrm{w}$ raję zaprzestali płacenia filurii, tym samym katun przestał pełnić funkcję podatkową. Spowodowało to upadek katunów, a Wołosi otrzymali te same obowiązki podatkowe, co rolnicy. Niektórzy Wołosi migrowali na tereny monarchii habsburskiej, licząc na to, że uda im się zachować swój dotychczasowy status i przywileje wodzów.

Jednak taka zmiana pozycji Wołochów nie oznaczała końca samorządów, które Wołosi w Imperium Osmańskim mieli od dawna. Ich przywódcy, w szczególności kniaziowie, stracili stare przywileje, ale zatrzymali swoje kompetencje. Ich rządy nie były już związane $z$ organizacją katuńską lecz z określoną przestrzenią geograficzną, na której osiedliła się ludność wołoska. Obszary znajdujące się pod kontrolą jednego kniazia nazwano kniaziostwami (serb. knežina). Funkcją kniazia i zgromadzenia męskich członków kniaziostwa było zapewnienie ludności samorządu w kniaziostwach. Tak ukształtowany samorząd pilnował porządku i zobowiązań podatkowych ludności w kniaziostwie. Samorząd ten akceptowała władza osmańska. Jej centra znajdowały się poza kniaziostwami, w miasteczkach, twierdzach i większych miastach ${ }^{69}$. Przedstawiciele wła-

${ }^{67}$ M. Vasić, op. cit., s. 247-278.

${ }^{68}$ A. Matkovski 1996, op. cit., s. 63; E. Miljković, op. cit., s. 66-67.

${ }^{69}$ M. Luković, Knežinska i plemenska samouprava kod Srba: poreklo institucija, „Naša Prošlost 2013, 14, s. 9-30. 
dzy osmańskiej na co dzień nie kontrolowali działań podejmowanych $\mathrm{w}$ kniaziostwach.

Na obszarach wysokogórskich dzisiejszej Czarnogóry, Hercegowiny i północnej Albanii - gdzie istniały warunki do odbywania sezonowych migracji pasterzy na stosunkowo krótkich szlakach między wioskami i letnimi pastwiskami - tworzone były podobne społeczności samorządowe. Wołoscy pasterze mieli już swoje osady u podnóży wysokich gór, gdzie wcześniej mieszkali także rolnicy. Tak ludność wołoska mieszała się z ludnością rolniczą. Pasterze zaczynali zajmować się również rolnictwem, a ludność rolnicza przejęła od Wołochów ich metodę pasterstwa, tj. sezonowe migracje. Wołoskie katuny integrowały się z wsiami. Osmańska władza powstałym społecznościom przyznawała prawo do samorzą$\mathrm{du}$, a $\mathrm{z}$ reguły i prawo do użytkowania pobliskich pastwisk, co doprowadziło do tego, że pastwiska stały się wspólną własnością. W strefie wysokich Gór Dynarskich (dzisiejsza Czarnogóra i Hercegowina) taki rodzaj jednostek samorządowych nazywano plemię (serb. pleme), a na podobnych obszarach Gór Šar i Pindos (dzisiejsza północna Albania) nazywano po albańsku - fis. Z katuńskiej organizacji przejęte zostały instytucje kniazia, wojewody oraz zgromadzenie. Te instytucje pełniły decydującą rolę w plemieniu. Funkcje kniaziów i wojewodów najczęściej były dziedziczone w rodzinach pochodzenia wołoskiego. Plemiona (fisy) często otrzymywały nazwy po poprzednich katunach. Plemię ustanawiało rodzaj suwerenności nad terytorium między swoimi wsiami a pobliskimi letnimi pastwiskami, które musiało ochraniać przed sąsiednimi plemionami. Wokół pastwisk dochodziło do częstych konfliktów. Wypasem owiec na pastwiskach rozporządzały rodziny wchodzące w skład plemienia. Tak ukształtowany samorząd plemiona akceptowała władza osmańska ${ }^{70}$. Jednak z czasem plemiona stały się źródłem oporu przeciwko niej, ponieważ sytuacja w Imperium Osmańskim ulegała zmianie.

Transformacja katuna w tajfę. Imperium Osmańskie zawsze było bardzo zainteresowane utrzymaniem i rozwojem pasterstwa w celu zaopatrzenia wojska i dużych miejskich ośrodków. Szczególną korzyścią było utrzymanie sezonowych migracji na długich szlakach między wysokimi górami Šar i Pindos oraz ciepłymi nizinami wokół mórz Egejskiego, Adriatyckiego i Jońskiego. Dzięki tym wędrówkom możliwe było hodowanie dużej liczby owiec, co przynosiło wielkie dochody państwu i pasterzom. Szanując wiekowe prawo zwyczajowe, państwo osmańskie nie mieszało się bezpośrednio w organizację działalności pasterskiej. Było przede wszystkim zainteresowane dochodami z pasterskich podatków

${ }^{70}$ Ibidem, s. 20-27. 
i miało wypracowany system pobierania opłat ${ }^{71}$. Kiedy pasterze nie płacili już filurii (ich status wołoski był unieważniony), Osmanowie pobierali od nich opłatę, tzw. podatek od małego stada lub owczarzyna (tur. adet-i agnam rüsûm $)^{72}$. To było główne opodatkowanie pasterzy: płacili go wszyscy posiadacze owiec i kóz, bez względu na to, czy wcześniej mieli status wołoski, czy status rolniczy. Chociaż były pewne różnice w wysokości tego podatku w pojedynczych sandżakach, które zależały od pozycji społecznej podatników, to prawie na całym terytorium Imperium Osmańskiego wnoszono do końca XVI wieku zwykle jedną akczę za dwie owce. Przychód z tego podatku przypadał państwu, ale kiedy nie został wpisany do defteru jako przychód określonego lenna (timar, ziamet, hass), to wtedy przypadał feudałowi, który dostał to lenno do użytku za życia. W czasie długotrwałej wojny austriacko-tureckiej (1683-1699) państwo osmańskie całkowicie przejęło przychód $\mathrm{z}$ tego podatku, aby podreperować podupadłe finanse. W Imperium Osmańskim w XIX w. (zwłaszcza w latach 1839 i 1857) przeprowadzano rozległe reformy całego systemu i wysokość podatku wzrastała, co negatywnie odbiło się na pasterstwie. Posiadacze bydła płacili jeszcze inne pomniejsze podatki (np. torovina).

W okresach stabilnych pastwiska należały do państwa lub (jako wspólna własność) wsi i innych samorządowych społeczności (plemię/ fis, kniaziostwo itd.). Mogły również należeć do islamskiej fundacji (tur. vakuf) lub chrześcijańskich monastyrów i cerkwi, a pod pewnymi warunkami mogły zostać własnością prywatną (tur. mülk). Państwo osmańskie miało też określone zasady regulowania opłat za użytkowanie zimowych i letnich pastwisk (resm-i yaylak, resm-i otlak). Wysokość opłaty zależała od jakości pastwiska i jakości owiec, ale z reguły wynosiła jedną owcę ze stada 100 sztuk, co było regulowane jednym przepisem (kânûnnnâme) sułtana Sulejmana Wspaniałego (1520-1566). Jeśli należność podatkowa za korzystanie z pastwiska była wpisana do defteru jako przychód określonego lenna, był to właśnie przychód feudała (spahis, bej), który dostał to lenno do użytku. Natomiast kiedy podatek nie został wpisany do defteru, wówczas feudałowie nierzadko nielegalnie gromadzili go na konto samorządowych jednostek, które miały prawo do tych pastwisk. W związku z tym $\mathrm{w}$ praktyce dochodziło do wielu sporó $\mathrm{w}^{73}$. Wędrówki pasterzy ze stadami na szlakach od letnich do zimowych pastwisk były regulowane prawem zwyczajowym jeszcze z okresu bizantyjskiego. Zarządzenie sułtana Su-

${ }^{71}$ A. Matkovski, op. cit., s. 65-97.

${ }^{72}$ H. Hadžibegić, Porez na sitnu stoku i korišćenje ispaša, „Prilozi za Orijentalnu Filologiju“", 8-10, 1958-1959, s. 63-109.

${ }^{73}$ A. Matkovski, op. cit., s. 97-106. 
lejmana Wspaniałego nakazywało poruszanie się po drogach, „którymi wędrowano od dawna", czyli od co najmniej 40-50 lat ${ }^{74}$.

Pozostaje pytanie, w jaki sposób pasterze organizowali się tam, gdzie odbywała się sezonowa migracja na długich szlakach: od gór Šar i Pindos do ciepłych nizin wybrzeży mórz Egejskiego, Adriatyckie i Jońskiego (wędrówka mogła trwać nawet 30 dni). Katun już nie istniał jako jednostka skarbowa, a pasterze płacili podatek „owczarzynę” w zależności od liczby owiec $\mathrm{w}$ stadzie. Jednak w sensie organizacyjnym katun miał swoją kontynuację $\mathrm{w}$ formie tajfy (tur. tâ'ifesi) lub karasznicy (w języku macedońskich Słowian karašnica ${ }^{75}$. Jak wcześniej wspomniano, tajfa była dobrowolnym zrzeszeniem pasterzy, ale nie stałym, lecz ad hoc, którego trwałość ograniczona była jednym sezonem wypasu w górach (ale można je było wznawiać w kolejnych sezonach). W tajfie stowarzyszali się krewni (często nawet bracia) i przyjaciele, którzy byli wspólnikami. Istniało duże zaufanie między wspólnikami, zwłaszcza wobec przywódcy tajfy, który u Arumunów nazywany był czelnikiem, a u innych bałkańskich pasterzy - ciehaja/ciaja ${ }^{76}$. Najczęściej pochodził z szanowanej pasterskiej rodziny. Czelnik (ciaja) zawierał umowy o zakupie pastwisk, zajmował się handlem (sprzedażą produktów mlecznych, wełny, owiec) i organizował prace pasterskie $\mathrm{w}$ trakcie letnich wypasów w górach oraz prowadził ogólne finanse. Regulował także pasterskie podatki. Całkowitą kwotę przychodów dzielił na wszystkich członków tajfy w zależności od ilości owiec, które każdy partner wniósł do tego zrzeszenia. Chociaż tajfa formalnie była organizacją powołaną na jeden sezon wypasania bydła, to bez wątpienia rozwinęła się ze średniowiecznego wołoskiego katunu, który spełniał te same funkcje gospodarcze w działalności pasterzy odbywających sezonowe migracje na długich szlakach. Dlatego w niektórych źródłach tajfa jest określana starym pojęciem $k^{\prime} t u n^{77}$.

Jednak turecki feudalizm (system spahisko-timarski) zaczął zmieniać się pod koniec XVI wieku. W czasie następnych dwóch-trzech wieków grunt, który wtedy uważany był za państwowy (tur. eraz-i miri), coraz częściej trafiał w prywatne ręce wysokich przedstawicieli klasy feudalnej (bejów). Był to proces tworzenia nowego rodzaju własności - czyftlików

${ }^{74}$ H. Hadžibegić, op. cit., s. 91-100.

${ }^{75}$ A. Matkovski, op. cit., s. 50-64.

${ }^{76}$ Tytuł čelnik ma pochodzenia słoweńskie (od słowiańskiego słowa čelo/czoło) i jest bardzo rozpowszechniony na Półwyspie Bałkańskim, a jego zastosowanie jest stare, sięga jeszcze średniowiecza. Również turecki termin ciehaja /ciaja (perskiego pochodzenia) używany jest w różnych rejonach Bałkanów. Por. G. Ostrogorski, F. Barešič, op. cit., s. 206-207; G. Vajgand, Aromuni, I, s. 228.

${ }^{77}$ Matkovski, op. cit., s. 57. 
(tur. çiftlik). W posiadaniu bejów coraz częściej znajdowały się również pastwiska górskie jak i te u wybrzeży i w ciepłych kotlinach, gdzie owce wypasano zimą. Ponadto zimowe pastwiska coraz częściej przekształcano w grunty rolne. Nabrało to tempa w połowie XIX wieku na tych obszarach, które były znane jako rozległe i ważne miejsca zimowych pobytów pasterzy, jak: Tesalia, okolice Salonik, Powardarie, dorzecze rzeki Marica i inne ${ }^{78}$. Tak więc sezonowe migracje pasterzy były znacznie utrudnione. Kiedy po wojnach bałkańskich w latach 1912-1913 ustalono nowe granice państw, sezonowe migracje odbywały się tylko w ich obszarach. Była to tylko blada pozostałość dawnych sezonowych wędrówek pasterzy na długich szlakach.

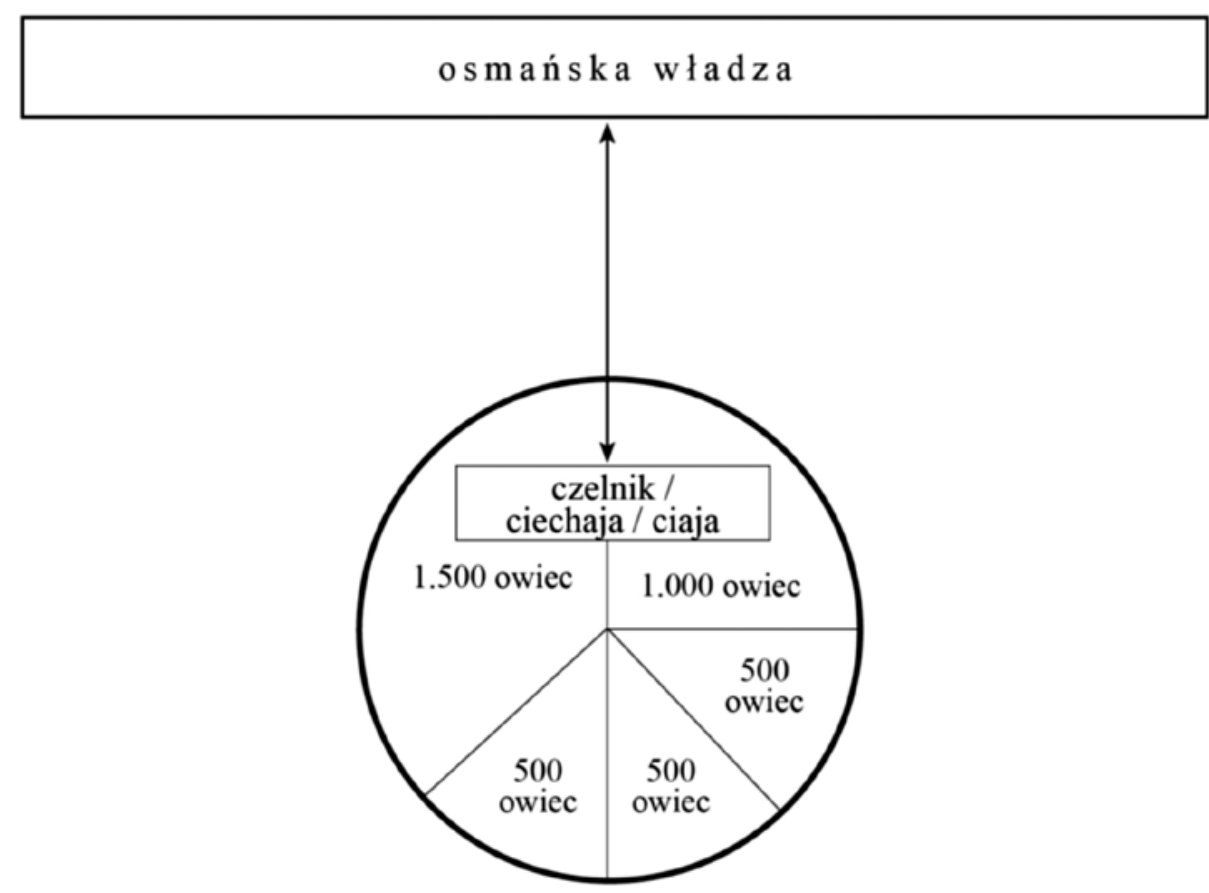

t a j f a

Ryc. 4. Przykład struktury tajfy, która posiada łącznie 4000 owiec: jeden wspólnik ma 1500 owiec, drugi wspólnik ma 1000 owiec, trzej pozostali mają po 500 owiec każdy (autor szkicu Miloš Luković)

${ }^{78}$ J. Cvijić, Balkansko poluostrvo, s. 215-227, 457-461; M. Zdraveva, G. Todorovski, op. cit., s. $41-70$. 
Sezonowe migracje pasterzy nie były charakterystyczne tylko na Bałkanach. Bardzo podobne zjawiska występowały (i występują do dzisiaj w ograniczonej postaci) w regionie Karpat. W związku z tym nasuwa się kwestia analogicznych zjawisk, form organizacyjnych i ich przemian, tj. historycznych procesów w tradycyjnym pasterstwie, na tych dwóch dużych sąsiadujących obszarach północno-wschodniej i środkowej Europy. Bardzo wiele zostało napisane na ten temat, ale mimo to poruszone zagadnienia wciąż pozostają otwarte na nowe sposoby analizy i porównań.

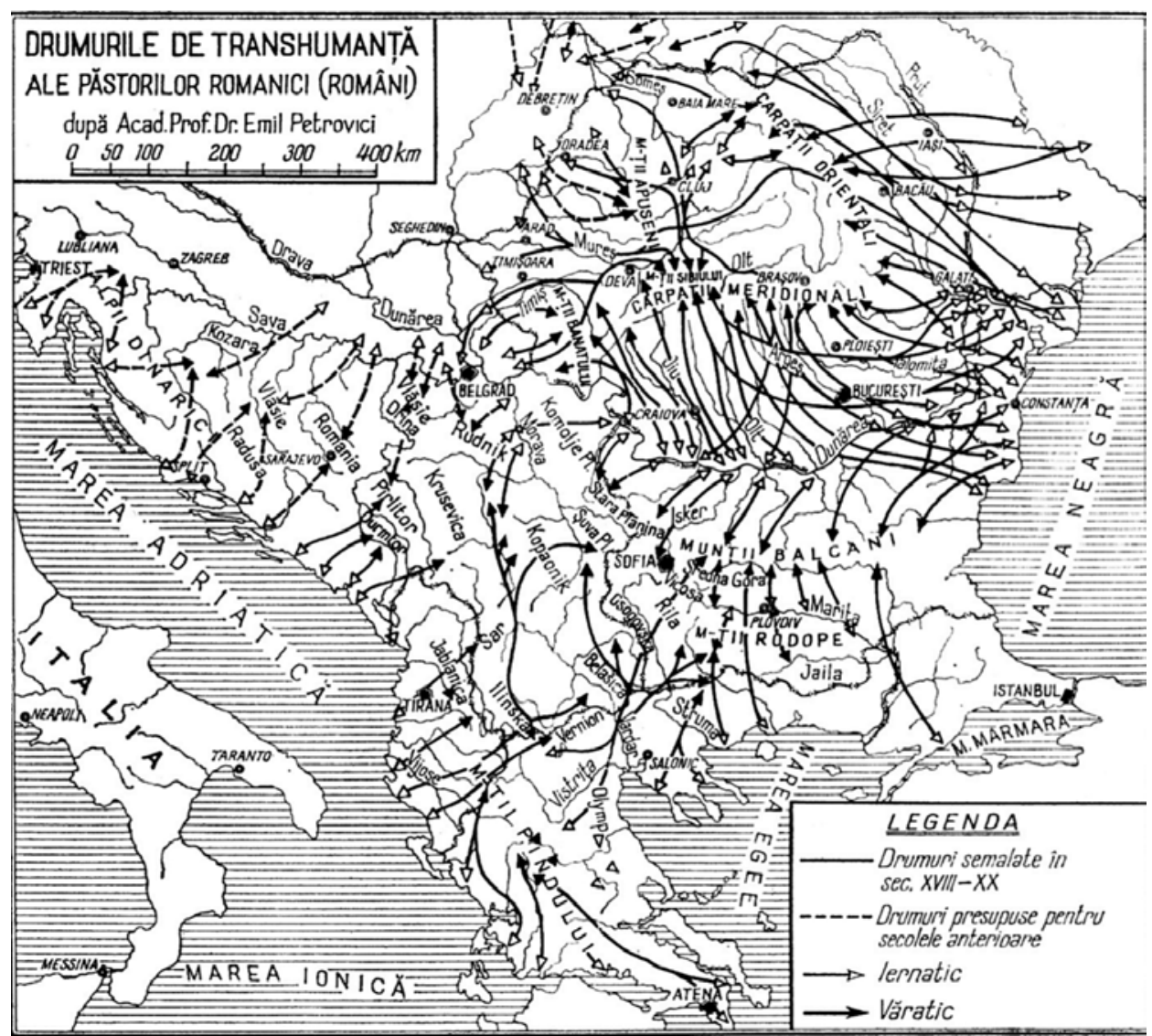

Ryc. 5. Sezonowe migracje pasterzy na Bałkanach i w regionie Karpat w okresie XVIII-XX wieku (N. Dunăre, Tipologie pastorale traditionnelle sud-est europeenne, w: Odredbe pozitivnog zakonodavstva i običajnog prava o sezonskim kretanjima stočara u jugoistočnoj Evropi. Zbornik radova sa međunarodnog naučnog skupa održanog 6. i 7. novembra 1975. u Beogradu, red. V. Čubrilović, Beograd 1976, s. 212. Autor mapy R. Petrovici) 


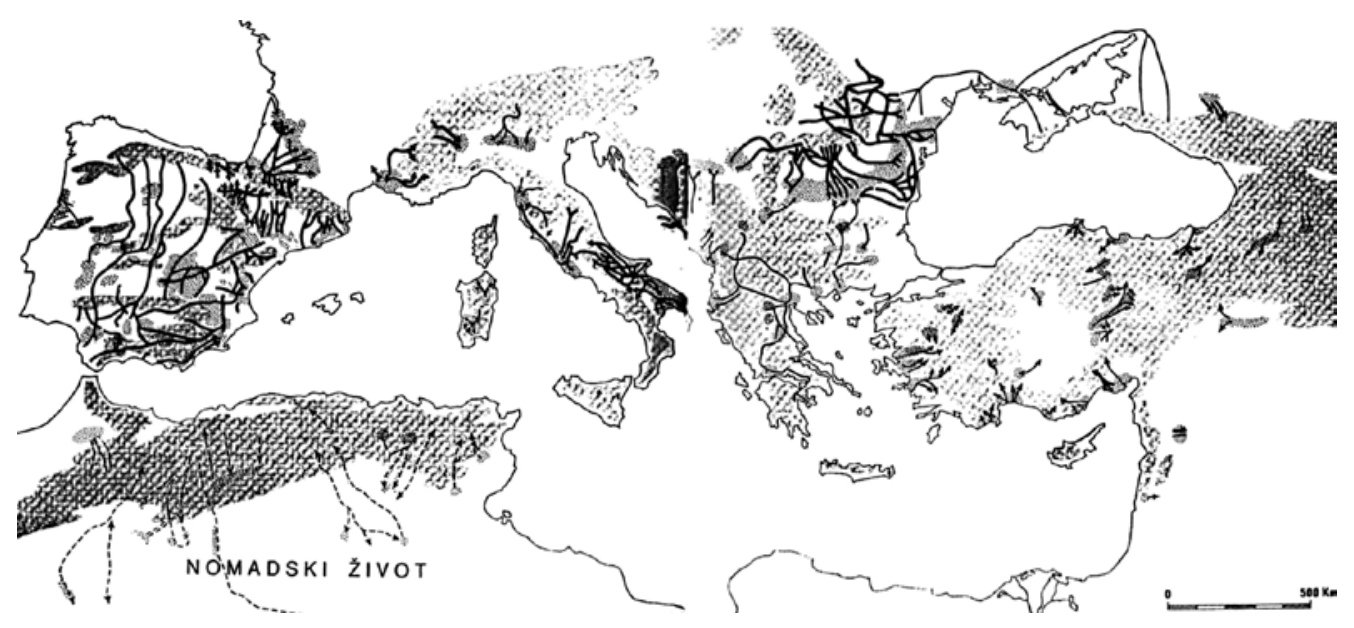

Ryc. 6. Sezonowe migracje pasterzy na obszarach otaczających Morze Śródziemne (F. Brodel, Mediteranski svet $u$ doba Filipa II, t. I, Beograd 2001, s. 94-95)

Oczywiście sezonowe migracje pasterzy istniały i istnieją nadal w innych częściach Europy (Półwysep Iberyjski, Półwysep Apeniński, Region Alpejski i inne) i na innych obszarach otaczających Morze Śródziemne (Azja Mniejsza, Bliski Wschód, Północna Afryka). Kiedy weźmie się to wszystko pod uwagę, można mówić nawet o specyficznym, oryginalnym sposobie rozwoju społeczeństwa. Coraz więcej badaczy kieruje swe zainteresowanie na te makroaspekty tradycyjnych sezonowych migracji pasterzy.

\section{BIBLIOGRAFIA:}

Aličić A., Katastarski popis Elajeta Bosna. Opširni katastarski popis za oblast Hercegovu iz 1585. godinu (Sveska I), Sarajevo 2014.

Aličić A., Poimenični popis Sandžaka vilajeta Hercegovina, Sarajevo 1985.

Angelov D., Agrarnite odnošenija v severna i sredna Makedonia prez XIV vek, Sofia 1954.

Begović M., Tragovi našeg srednjovekovnog prava u turskim pravnim spomenicima, „Istoriski Časopis“ 1951/1952, 3, s. 67-84.

Blagojević M., Posebni zakoni na manastirskim vlastelinstvima, [w:] Srednjovekovno pravo u Srba u ogledalu istorijskih izvora. Zbornik sa naučnog skupa održanog 19-21. marta 2009, red.

S. Ćirković, K. Čavoški, Beograd 2009, s. 21-33.

Blagojević M., Vlaški knezovi, primićuri i čelnici u državi Nemanjića i Kotromanića (13-14. vek), [w:] Spomenica Milana Vasića, red. R. Mihaljčić, Banja Luka 2005, s. 43-75.

Blagojević M., Zemljoradnja u srednjovekovnoj Srbiji, Beograd 1973.

Bojanić D., Turski zakoni i zakonski propisi iz XV i XVI veka za smederevsku, kruševačku i vidinsku oblast, Beograd 1974.

Braudel F., Mediteranski svet u doba Filipa II, Beograd 2001. 
Capidan T., Meglenoromănil̆, Memoriile Sectiunii literare. Ser. 3, t. 2. Mem., Cluj 1925.

Cvetković M., Uključivanje Slovena $i$ Vlaha u provincijske organizacije na jugu Balkana do XI veka. Sličnosti i razlike, „Zbornik Radova Vizantološkog Instituta“ 2012, s. 19-41.

Cvijić J., Antropogeografski problemi Balkanskog poluostrva, Srpski etnografski zbornik (serija: Naselja srpskih zemalja. Rasprave i građa) IV, Beograd 1902, s. I-CCXXXVI.

Cvijić J., Balkansko poluostrvo i južnoslovenske Zemle, Beograd 1966.

Cvijić J., La Péninsule balkanique: géographie humaine, Paris 1918.

Ćirković S., Rabotnici, vojnici, duhovnici. Društva srednjovekovnog Balkana, Beograd 1997.

Dragomir S., Vlahii din Serbia în sec. XII-XV, "Anuarul Institutului de Istorie Națională" 1921/1922, s. 279 -299.

Đurđev B., Teritorijalizacija katunske organizacije do kraja XV vijeka (katun - knežina - pleme), w: Simpozijum o srednjovjekovnom katunu održan 24. i 25. novembra 1961. g., red. M. Filipović, Sarajevo 1963, s. 143-169.

Enciklopedija Jugoslavije, t. 5, gl. red. M. Krleža, Zagreb 1957.

Filipović M., Katun u našoj istoriografiji. Struktura i organizacija srednjovekovnih katuna, [w:] Simpozijum o srednjovjekovnom katunu održan 24. i 25. novembra 1961. g., red. M. Filipović, Sarajevo 1963.

Filipović N., Islamizacija Vlaha u Bosni i Hercegovini u XV i XVII vijeku, [w:] Simpozijum: Vlasi u XV i XVI vijeku (Sarajevo, 13-16. XI 1973). Referati i saopštenja. Diskusija, „Radovi ANUBIH“, 73, red. D. Kovačević-Kojić, Sarajevo 1983, s. 139-148.

Flipović N., Pogled na osmanski feudalizam, „Godišnjak Istoriskog Društva Bosne i Hercegovine“ 1952, 4, s. 102-113.

Gyöni M., La Transhumance des Vlaques Balkaniques au Moyen Age, „Byzantoslavica” 1951, 12, s. 29-42.

Hadžibegić H., Porez na sitnu stoku i korišćenje ispaša, „Prilozi za Orijentalnu Filologiju“ 1958-1959, 8-10, s. 63-109.

Holland H., Travels in Albania, London 1819.

Hrabak B., Čelnici stočarskih zajednica u istočnoj Hercegovini u XIII-XIV veku, [w:] Zbornik za istoriju Bosne i Hercegovine, 2, red. M. Ekmečić, Beograd 1997, s. 139-172.

Hrabak B., Iz starije prošlosti Bosne i Hercegovine, knj. II, Beograd 2003.

İnalcik H., Filori, [w:] Diyanet Vakfi İslam Ansiklopedisi, vol. 13, Istanbul 1996, s. 106-107.

İnalcik H., Od Stefana Dušana do Osmanskog carstva, „Prilozi za Orijentalnu Filologiju“ 1953, 3, 1, s. 23-55.

İnalcik H., Osmansko carstvo. Klasično doba, Beograd 1974.

İnalcik H., The Yürüks: Their Origins, Expansion an Economic Role, [w:] The Middle East and the Balcans under Ottoman Empire. Esseys on Economy and Society, Bloomington 1993, s. 39-65.

Jireček K., Cesty po Bulharsku, Praha 1888.

Jireček K., Die Handelsstrassen und Bergwerke von Serbien un Bosnien während des Mittelalters, Prag 1879.

Jireček K., Geschichte der Serben, Bd 2, Gotha 1918.

Jireček K., Trgovački putevi i rudnici Srbije i Bosne u srednjem vijeku, [w:] Zbornik Konstantina Jirečeka I, red. M. Dinić, Beograd 1959, s. 295-304.

Kadlec K., Valaši a valašské právo v zemích slovanských a uherskýh, Praha 1916.

Katić R., Stočarstvo srednjovekovne Srbije, Begrad 1978.

Klaić N., Izvori za hrvatsku povijest do 1526. godine, Zagreb 1972.

Kovačević D., Srednjovjekovni katun po dubrovačkim izvorima, [w:] Simpozijum o srednjovjekovnom katunu održan 24. i 25. novembra 1961. g., red. M. Filipović, Sarajevo 1963. 
Kursar V., Being an Ottoman Vlach: on Vlach Identity (Ies), Role and Status in Western Parts of the Ottoman Balkans ( $15^{\text {th }}-18^{\text {th }}$ Centuries), „OTAM. Ankara Üniversitesi Osmanlı Tarihi Araştırma ve Uygulama Merkezi Dergisi" 2013, 24, 34, s. 115-161.

Leake W. M., Travels in northern Greece, London 1835.

Leksikon srpskog srednjeg veka, red. S. Ćirković, R. Mihaljčić, Beograd 1999.

Luković M., Balkanistika (balkanologie) v Srbsku v obdobi 1991-2013, „Historica. Revue pro historii a př́buzné vědy“ 2014, s. 86-104.

Luković M., Balkanlarda Besicilerin Transhumance Hareketleri ve Balkan Savaşları'nın Besicilerin Mevsimsel Hareketlerine Etkisi / Transhumance Movement at Cattle Raisers in the Balkans and the Impact of Balkan Wars on Their Seasonal Moves, "History Studies. International Journal of History“ 2013, 5, 6, s. 41-58.

Luković M., Katun a katunská organizace středověkých Vlachů v centrálních a západních oblastech Balkánu, „Slovanský Přehled“ 2013, 5, s. 21-60.

Luković M., Knežinska i plemenska samouprava kod Srba: poreklo institucija, „Naša Prošlost 2013, 14, s. 9-30.

Luković M., Stočarska privreda kao činilac oblikovanja narodne kulture Srba, [w:] Narodna kultura Srba između Istoka i Zapada, red. L. Radenković, Beograd 2014.

Marcu L., Formes traditionnelles d'élevage pastoral et systèmes d'organisation chez les Vlaques balkaniques, [w:] Odredbe pozitionog zakonodavstva i običajnog prava o sezonskim kretanjima stočara u jugoistočnoj Evropi. Zbornik radova sa međunarodnog naučnog skupa održanog 6. i 7. novembra 1975. u Beogradu, red. V. Čubrilović, Beograd 1976.

Marković M., Stočarska kretanja u dinarskim planinama, „Zbornik za Narodni Život i Običaje Južnih Slavena" 1971, 45, s. 523-549.

Matkovski A., Nomadskoto stočartvo vo Makedonija od XIV do XIX vek, Skopje 1996.

Mihačević L., Po Albaniji. Dojmovi s puta, Zagreb 1911.

Miljković E., Vlasi u domaćoj istoriografiji (1960-2010), „Braničevski Glasnik” 2010, 7, s. 5-22.

Mrgić J., Zemlja i ljudi: Iz istorije životne sredine zapadnog Balkana, Beograd 2013.

Mutavdžić P., Balkan i balkanologija: uvod u studije jugoistočne Evrope, Beograd 2013.

Naselja srpskih zemalja: naselja, poreklo stanovništva, običaji, red. B. Čeliković, Beograd 2011.

Ostrogorski G., Barešić F., Vizantijski izvori za istoriju naroda Jugoslavije I, Beograd 1966.

Pavković N., Studije i ogledi iz pravne etnologije, u izdanju Srpskog genealoškog centra, Beograd 2014, s. 165-172.

Pavlović S., Istorija Balkana 1804-1945, Beograd 2001.

Picot E., Les Roumains de la Macédoine, Paris 1875.

Pouqueville F., Voyage de la Grèce, Paris 1824.

Rovinski P. A., Czernogoria v eja proszlom i nastojasztem, Sanktpeterburg 1897.

Šabanavić H., Bosanski pašaluk, Sarajevo 1982.

Skok P., Iz rumunske literature o balkanskim Vlasima. III-IV, "Glasnik Skopskog Naučnog Društva" 1928, 2, 3-4, s. 293-308.

Škrivanić G., Putevi u srednovekovnoj Srbiji, Beograd 1974.

Smajić R., Pravci razvoja osmanistike u jugoslovenskom i postjugoslovenskom periodu, [w:] Naučno djelo Branislava Đurđeva. Zbornik radova sa međunarodnog okruglog stola održanog u Sarajevu 4. decembra 2009, red. Dž. Juzbašić, Sarajevo 2010, s. 93-100.

Sorescu-Marinković A., Româii din Timoc astăzi. Flinţe mitologice, Cluj-Napoca 2012.

Stojanovski A., Administrativno-teritorijalnata podelba na Makedonija pod osmanskata vlast do krajot na XVII vek, "Glasnik na Institutot za Nacionalna Istorija“ 1973, 2, s. 129-145.

Vasić M., Knežine i knezovi timarlije u Zvorničkom sandžaku u XVI vijeku, "Godišnjak Istoriskog Društva Bosne i Hercegovine“ 1959, 10, s. 247-278. 
Wace A. J. B., Thompson M. S., Balkanski nomadi: prikaz života i običaja Vlaha sa severnih Pinda, Pančevo 2009.

Wace A. J. B., Thompson M. S., The nomads of the Balkans: an acocount of life and customs among the Vlachs of northern Pindus, London 1914.

Weigand G, Aromuni, I-II, Beograd 1995.

Weigand G., Die Aromunen, I-II, Leipzig 1894-1895.

Zbornik na trudovi od Meǵunarodniot naučen simpozijum Vlasite na Balkanot održan na 7-8 noemvri 2003 vo Skopje, red. S. Kiselinovski, D. Dimčev, Skopje 2005.

Zdraveva M., Todorovski G., Nomadskoto stočarstvo vo Makedonija vo XIX vek do 1918, Skopje 1997.

Zeune J. A., Balkanhalbinsel, Berlin 1808.

Zirojević O., Tursko vojno uređenje u Srbiji 1459-1683, Beograd 1974.

\section{ABSTRACT:}

Over a long period of history the predominant type of livestock raising in the Balkans was based on seasonal movements of people and their large sheep or (to a lesser extent) goat flocks between summer and winter pastures. During the summer livestock was grazed on high pastures in the mountains, and in the autumn it was driven to warm coastal plains, dales or river valleys where there was enough grass until the next spring vegetation season in the mountains. This type of animal husbandry was subject to constant change in a centuries-long process which saw different phases and took different courses in different parts of the Balkans (depending on the concrete geographical, social and political circumstances). For all changes it had undergone during the medieval period and a few centuries of Ottoman rule, the practice of large-scale seasonal livestock migration continued until the twentieth century. The practice still survives, though on a considerably reduced scale and in a modified form. This paper discusses the following questions: the influence of political changes on seasonal livestock movements in the Balkans from the end of the eighteenth century to the beginning of the twentieth century; information about seasonal livestock movements in the Balkans provided by travellers and scholars; recent zones of seasonal livestock movements in the Balkans; the social organization and status of Vlach herders in the Balkans in the middle ages; changes in the status and mode of organization of seasonal herders in the Ottoman period. In this connection, the term "the Balkan Peninsula/the Balkans" has been clarified.

Key words: Balkans, herders, seasonal migrations, historical background, transhumance movement

Miloš Luković jest pracownikiem Instytutu Bałkanologii Serbskiej Akademii Nauk i Sztuk w Belgradzie. Ukończył prawo, a potem filologię (serbokroatystykę) w Belgradzie. Studia doktoranckie kończył w Nowym Sadzie. Był lektorem języka serbo-chorwackiego na Uniwersytecie Jagiellońskim w Krakowie w latach 1987-1989. Mówi po polsku, macedońsku i angielsku. Jest autorem prac z dziedziny onomastyki, stylistyki funkcjonalnej, historii serbskiego języka literackiego oraz etnicznej historii Kosowa i całej Serbii południowej. Kontakt: miloslukovic@gmail.com. 